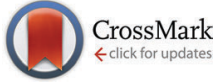

Cite this: Phys. Chem. Chem. Phys., $2015,17,10040$

Received 12th December 2014 Accepted 4th March 2015

DOI: $10.1039 / \mathrm{c} 4 \mathrm{cp} 05820 \mathrm{~h}$

www.rsc.org/pccp

\section{Ag plasmonic nanostructures and a novel gel electrolyte in a high efficiency $\mathrm{TiO}_{2} / \mathrm{CdS}$ solar cell $\dagger$}

\author{
P. Naresh Kumar, ${ }^{a}$ Melepurath Deepa*a and Avanish Kumar Srivastavab
}

A novel photoanode architecture with plasmonic silver ( $\mathrm{Ag}$ ) nanostructures embedded in titania $\left(\mathrm{TiO}_{2}\right.$ ), which served as the wide band gap semiconducting support and CdS quantum dots (QDs), as light absorbers, is presented. Ag nanostructures were prepared by a polyol method and are comprised of clumps of nanorods, 15-35 nm wide, interspersed with globular nanoparticles and they were characterized by a face centered cubic lattice. Optimization of Ag nanostructures was achieved on the basis of a superior power conversion efficiency (PCE) obtained for the cell with a $\mathrm{Ag} / \mathrm{TiO}_{2} / \mathrm{CdS}$ electrode encompassing a mixed morphology of Ag nano-rods and particles, relative to analogous cells with either Ag nanoparticles or Ag nanorods. Interfacial charge transfer kinetics was unraveled by fluorescence quenching and lifetime studies. Ag nanostructures improve the light harvesting ability of the $\mathrm{TiO}_{2} / \mathrm{CdS}$ photoanode via (a) plasmonic and scattering effects, which induce both near- and far-field enhancements which translate to higher photocurrent densities and (b) charging effects, whereby, photoexcited electron transfer from $\mathrm{TiO}_{2}$ to $\mathrm{Ag}$ is facilitated by Fermi level equilibration. Owing to the spectacular ability of Ag nanostructures to increase light absorption, a greatly increased PCE of $4.27 \%$ and a maximum external quantum efficiency of $55 \%$ (at $440 \mathrm{~nm}$ ) was achieved for the cell based on $\mathrm{Ag} / \mathrm{TiO}_{2} / \mathrm{CdS}$, greater by 42 and $66 \%$, respectively, compared to the $\mathrm{TiO}_{2} / \mathrm{CdS}$ based cell. In addition, the liquid $\mathrm{S}^{2-}$ electrolyte was replaced by a $\mathrm{S}^{2-}$ gel containing fumed silica, and the redox potential, conductivity and p-type conduction of the two were deduced to be comparable. Although the gel based cells showed diminished solar cell performances compared to their liquid counterparts, nonetheless, the $\mathrm{Ag} / \mathrm{TiO}_{2} / \mathrm{CdS}$ electrode continued to outperform the $\mathrm{TiO}_{2} / \mathrm{CdS}$ electrode. Our studies demonstrate that Ag nanostructures effectively capture a significant chunk of the electromagnetic spectrum and aid QD solar cells in delivering high power conversion efficiencies.

\section{Introduction}

Quantum dot solar cells (QDSCs) have spurred considerable research interest in the realm of energy harvesting devices. They are promising low cost alternates to other competing technologies such as bulk heterojunction- and dye sensitized-solar cells (DSSCs). Other advantageous attributes which advocate the use of QDs for developing solar cells include: ease of processing, tunable band gap (adjusted by control of the QD size) and multiple exciton generation (the possibility of producing more

\footnotetext{
${ }^{a}$ Department of Chemistry, Indian Institute of Technology Hyderabad, Ordnance Factory Estate, Yeddumailaram-502205, Telangana, India. E-mail: mdeepa@iith.ac.in; Fax: +91-40-23016003; Tel: +91-40-23016024

${ }^{b}$ CSIR-National Physical Laboratory, Dr. K. S. Krishnan road, New Delhi-110012, India

$\dagger$ Electronic supplementary information (ESI) available: $J-V$ characteristics of different photoanodes, FE-SEM images of photoanodes, CV plots of electrolytes, EQE plot of bare $\mathrm{TiO}_{2}$ and electron microscopy images of MWCNTs. See DOI: $10.1039 / \mathrm{c} 4 \mathrm{cp} 05820 \mathrm{~h}$
}

than one electron per impinging photon). ${ }^{1}$ The light harvesting assembly in a QDSC typically comprises of narrow band gap quantum dots (e.g. CdS, ${ }^{2-4} \mathrm{CdSe},{ }^{5-7} \mathrm{CdTe},{ }^{8} \mathrm{PbSe},{ }^{9} \mathrm{PbS},{ }^{10,11} \mathrm{InP}^{12}$ etc.) tethered either by a linker or directly to a wide band gap semiconducting scaffold of $\mathrm{ZnO}$ or $\mathrm{TiO}_{2}$ or $\mathrm{SnO}_{2}$. Poor linking of the dots to the oxide, inadequate loading of the dots onto the oxide layer and rapid back electron transfer rates are the reasons for the inferior performance of QDSCs compared to DSSCs. ${ }^{13}$ The highest power conversion efficiencies (PCEs) reported for QDSCs lie in the range of $3-7 \%,{ }^{14-17}$ as opposed to values of $6-12 \%$ achieved in DSSCs. ${ }^{18-20}$ Despite the performance difference, the cost-effective aspect of QDSCs compared to the use of expensive dyes in DSSCs provides the impetus for designing new architectures for QDSCs, wherein an excellent tradeoff between cost and efficiency can be achieved.

One innovative but simple strategy that has been successfully employed in the past to improve PCEs of DSSCs involves the incorporation of plasmonic metal nanoparticles (NPs) in mesoporous $\mathrm{TiO}_{2}{ }^{21}$ The localized surface plasmon resonance (LSPR) 
effect is defined as the collective oscillations of free electrons on the metal surface, which can be directly excited by the electric field of the incoming solar radiation, when the impinging energy matches with the energy of the oscillation. ${ }^{22-24}$ The resonance excitation induces strong scattering and absorption of light. In addition, the local field in the proximity of semiconducting particles (dye molecules or QDs) is enhanced relative to the incoming field and therefore additional electron-hole pairs are generated in the plasmonic photoanode. Spherical nanoparticles exhibit a narrowband LSPR, and therefore the near-field enhancement is confined to a constricted wavelength span. By using elongated metal shapes like wires or rods, instead of spheroids, the LSPR increments can be realized over wider wavelength ranges, as both the transverse and longitudinal modes corresponding to the short and long axes of the metal nanoparticles usually produces peaks in the visible and NIR wavelength regions. Furthermore, light scattering by larger sized metal nanoparticles $(>50 \mathrm{~nm}$ ) also improves absorption of the semiconductor nanocrystals, which can again lead to higher photocurrents. The electron accepting ability of metal nanoparticles, via a suitably positioned Fermi level, aids in enhancing the charge transfer to the current collector.

A recent study on $\mathrm{SiO}_{2} @ \mathrm{TiO}_{2} @ A u N P$ and $\mathrm{SiO}_{2} @ A u N P @ \mathrm{TiO}_{2}$ spheres incorporated in a DSSC resulted in PCE increments by 14 and $10 \%$, respectively, with respect to a similar cell devoid of $\mathrm{Au} \mathrm{NPs.}{ }^{25}$ In another report, $\mathrm{Au} @ \mathrm{SiO}_{2} @ \mathrm{TiO}_{2}$ aggregates, upon inclusion in the DSSC photoanode, yielded an average PCE increase from 2.81 to $5.52 \%$, which was confirmed by the authors as an outcome of near-field broadband plasmonic enhancement. ${ }^{26}$ A remarkable architecture for a DSSC, employing an $\mathrm{Ag}$ nanodome array, enabled increased absorption due to light scattering and coupling to propagating surface plasmon polariton modes, which in turn manifested in short circuit current density increments by 16 and $12 \%$, for two different dyes. ${ }^{1}$ In another study, the advantage of longitudinal SPR mode was exploited in addition to the transverse mode in a DSSC by use of Au-Ag alloy popcorn-shaped core-shell nanoparticles and as a consequence of this broadband light absorption, an increase in PCE, by $32 \%$, was realized. ${ }^{27}$ In another report of note, the roles of plasmonic and charging effects in improving the photocurrent and photovoltage, respectively, of a DSSC, were unambiguously distinguished by use of Au@SiO ${ }_{2}$ and $\mathrm{Au} @ \mathrm{TiO}_{2}$ core-shell nanoparticles. ${ }^{28}$ A panchromatic DSSC with an increased PCE from 8.3 to $10.8 \%$, achieved via plasmon enhanced photo-absorption in the otherwise less harvested domain of the electromagnetic spectrum, was demonstrated by Dang et $a l^{29}$ The same group showed that the use of plasmonic Ag@TiO nanoparticles not only effected a PCE increase from 7.8 to $9 \%$, for a DSSC, but this increment could be achieved by the use of $25 \%$ less photoactive material. ${ }^{24}$ The influence of shell thickness of $\mathrm{Au} @ \mathrm{TiO}_{2}$ core-shell nanoparticles on the plasmonic enhancement effect in DSSCs and its optimization was probed in an earlier study. ${ }^{30}$

While the plasmonic effect of metal nanostructures has been widely used for bringing about significant improvements in the solar cell performance characteristics of DSSCs, reports on the use of plasmonics in QDSCs are scarce. ${ }^{23}$ To bridge this lacuna and with the objective of developing and demonstrating a high performance QDSC, in this report, a heretofore unreported photoanode architecture of $\mathrm{Ag}$ nanostructures (nanorods cum nanoparticles) integrated with a $\mathrm{TiO}_{2} / \mathrm{CdS}$ assembly, is presented. $\mathrm{Ag}$ nanostructures were grown by using a previously reported polyol method. ${ }^{31}$ The solar cell performance dependence on the morphology of Ag nanostructures allowed for the optimization of this co-existing nano-rod/particle morphology for the development of the champion QDSC. CdS QDs were grown by successive ionic layer absorption and reaction (SILAR) either on a $\mathrm{TiO}_{2}$ or a $\mathrm{TiO}_{2} / \mathrm{Ag}$ layer, which, in turn, was deposited on a pre-fabricated layer of $\mathrm{Ag}$ nanostructures. Microstructural analysis was performed using electron microscopy. QDSCs were assembled using both liquid and gel electrolytes with $\mathrm{S}^{2-}$ as the ionic species and multiwalled carbon nanotubes or MWCNTs as the counter electrode. Charge transfer and transport mechanisms and the ability of the $\mathrm{Ag}$ nanostructured plasmons to dramatically increase the PCE of a QDSC based on a $\mathrm{Ag} / \mathrm{TiO}_{2} / \mathrm{CdS}$ assembly, relative to a cell with a $\mathrm{TiO}_{2} / \mathrm{CdS}$ electrode, was studied by absorption, fluorescence quenching and decay analyses, $J-V$ and external quantum efficiency (EQE) measurements. The properties of the $\mathrm{S}^{2-}$ gel electrolyte (prepared by simply using fumed silica, as the gelatinizing agent), such as conductivity, p-type behavior and oxidation potential were compared with that of the corresponding liquid electrolyte. The suitability of the $\mathrm{S}^{2-}$ gel for fabricating quasi solid state QDSCs and the power of Ag nanostructures in effecting drastic improvements in the PCE $(>4 \%)$ of a QDSC clearly shows that high efficiency QDSCs can be realized.

\section{Experimental}

\subsection{Chemicals}

Cadmium acetate $\left(\mathrm{Cd}\left(\mathrm{CH}_{3} \mathrm{COO}\right)_{2}\right)$, sodium sulfide $\left(\mathrm{Na}_{2} \mathrm{~S}\right)$, acetylacetone, ethylene glycol and solvents: methanol or $\mathrm{MeOH}$ and toluene were obtained from Merck. Silver nitrate $\left(\mathrm{AgNO}_{3}\right)$, titanium tetrachloride $\left(\mathrm{TiCl}_{4}\right)$, poly (vinylpyrrolidone $)\left(M_{\mathrm{W}}\right.$ (number average $)=$ 24000 ) or PVP and MWCNTs (purity $>90 \%$, outer diameter: 10-15 nm, inner diameter: 2-6 nm, length 0.1-10 $\mu \mathrm{m}$, melting point: $3652-3697{ }^{\circ} \mathrm{C}$ ) were procured from Aldrich. $\mathrm{TiO}_{2}$ powder (P25) was a free gift from Evonik and fumed silica was a gift from Cabosil. Deionized water with a resistivity of $\sim 18.2 \mathrm{M} \Omega \mathrm{cm}$ was obtained from a Millipore Direct-Q3 UV system. Inorganic transparent electrodes of $\mathrm{SnO}_{2}: \mathrm{F}$ coated glass (FTO, sheet resistance: $14 \Omega \mathrm{sq}^{-1}$ ) were obtained from Pilkington and were cleaned in a soap solution, $30 \% \mathrm{HCl}$ solution, double distilled water and acetone, in that sequence prior to use.

\subsection{Preparation of electrodes}

$\mathrm{Ag}$ nanostructures were prepared using a procedure defined in an earlier report. ${ }^{31} 3 \mathrm{~mL}$ of $\mathrm{AgNO}_{3}(0.1 \mathrm{M})$ solution in EG and $3 \mathrm{~mL}$ of EG with PVP (264 mg), were injected slowly into $5 \mathrm{~mL}$ of EG placed in a two necked round bottom flask, maintained at $160{ }^{\circ} \mathrm{C}$ while being magnetically stirred, and the resulting formulation was refluxed at $160{ }^{\circ} \mathrm{C}$ for three different intervals of 20, 40 and $60 \mathrm{~min}$ with continuous stirring. The reduced $\mathrm{Ag}$ 
product was extracted at the end of each interval and then centrifuged using acetone as the solvent; the supernatant was discarded and the process was repeated two more times, and the precipitate was collected, in each case.

For preparing the $\mathrm{TiO}_{2}$ plates, a paste of $\mathrm{TiO}_{2}$ powder was prepared in a clear solution of ultrapure water and acetylacetone with a ratio of $5.66: 1$, applied on a clean FTO substrate by doctor blading and the resulting film was heated at $80{ }^{\circ} \mathrm{C}$ for $30 \mathrm{~min}$ which was followed by annealing at $500{ }^{\circ} \mathrm{C}$ for another $30 \mathrm{~min}$. The same procedure was repeated and a second layer of $\mathrm{TiO}_{2}$ was obtained. The ramp for the annealing at $500{ }^{\circ} \mathrm{C}$ every time was fixed at $4{ }^{\circ} \mathrm{C} \mathrm{min}{ }^{-1}$. The resulting $\mathrm{TiO}_{2}$ films were immersed in a $0.04 \mathrm{M}$ aqueous $\mathrm{TiCl}_{4}$ solution at $70{ }^{\circ} \mathrm{C}$ for $25 \mathrm{~min}$, followed by rinsing in ultrapure water and the $\mathrm{TiO}_{2}$ coated plates were obtained. The final Ag product obtained after centrifugation, at the end of each reflux span, was used for preparation of photoanodes. A suspension of $\mathrm{Ag}$ product (20 or 40 or 60 min-product) was prepared by using a $1.8 \mathrm{mg} \mathrm{mL}^{-1}$ concentration, followed by ultrasonication for $15 \mathrm{~min}$. The suspension was spin coated at $2500 \mathrm{rpm}$ for $60 \mathrm{~s}$ on $\mathrm{TiO}_{2}$ plates, rinsed in toluene and air-dried. This process was repeated twice to allow the percolation of $\mathrm{Ag}$ nanoparticles into the $\mathrm{TiO}_{2}$ pores, and/or a uniform coating of $\mathrm{Ag}$ nanorods over the $\mathrm{TiO}_{2}$ film. The film is labelled as $\mathrm{Ag} / \mathrm{TiO}_{2}$. CdS QDs were deposited over the $\mathrm{Ag} / \mathrm{TiO}_{2}$ plate by using the SILAR method, from clear solutions of $\mathrm{Cd}\left(\mathrm{CH}_{3} \mathrm{COO}\right)_{2}(0.1 \mathrm{M})$ and $\mathrm{Na}_{2} \mathrm{~S}(0.1 \mathrm{M})$ in $\mathrm{MeOH}$ as cadmium and sulfide precursors, respectively. The two solutions were again taken in two separate beakers. The $\mathrm{Ag} / \mathrm{TiO}_{2}$ film was dipped in the $\mathrm{Cd}\left(\mathrm{CH}_{3} \mathrm{COO}\right)_{2}$ solution for $2 \mathrm{~min}$, rinsed in methanol to remove excess ions, followed by drying. It was then dipped in the $\mathrm{Na}_{2} \mathrm{~S}$ solution for $2 \mathrm{~min}$, again followed by a methanol rinse and drying and this is regarded as one cycle of CdS deposition. In a similar way, 6 more cycles were performed and an $\mathrm{Ag} / \mathrm{TiO}_{2} / \mathrm{CdS}$ electrode was obtained. The $\mathrm{Ag} / \mathrm{TiO}_{2} / \mathrm{CdS}$ electrodes were prepared by using each of the three $\mathrm{Ag}$ products obtained at the end of 20, 40 and 60 min reflux times. For preparing control $\mathrm{TiO}_{2} / \mathrm{CdS}$ plates, the $\mathrm{TiO}_{2}$ plates were subjected to 7 cycles of SILAR in $\mathrm{Cd}\left(\mathrm{CH}_{3} \mathrm{COO}\right)_{2}$ and $\mathrm{Na}_{2} \mathrm{~S}$ solutions and the $\mathrm{TiO}_{2} / \mathrm{CdS}$ electrode was obtained.

MWCNTs (200 mg) were added to $60 \mathrm{~mL}$ of $1: 3 \mathrm{v} / \mathrm{v}$ solution of $\mathrm{H}_{2} \mathrm{SO}_{4}: \mathrm{HNO}_{3}$ (each of $6 \mathrm{M}$ strength) and refluxed for $12 \mathrm{~h}$ at $80{ }^{\circ} \mathrm{C}$. After cooling to room temperature, the reaction mixture was diluted with ultrapure water $(50 \mathrm{~mL})$ and then washed with ultrapure water till the supernatant showed neutral $\mathrm{pH}$. Using ashless fast filter paper ( $\varnothing 150 \mathrm{~mm}$ ), the resulting brown colored solid was collected, dried at room temperature and dispersed in water by sonication for $2 \mathrm{~h}$. By using electrophoretic deposition at $60 \mathrm{~V}$, a thin layer of functionalized MWCNTs was deposited over FTO/glass substrates and the films were washed in water and dried in air and used as a counter electrode for photovoltaic measurements.

\subsection{Device construction}

A gel electrolyte was prepared by dissolving $\mathrm{Na}_{2} \mathrm{~S}(0.1 \mathrm{M})$ in a solution containing $3: 7 \mathrm{v} / \mathrm{v}$ of water: $\mathrm{MeOH}$, followed by addition of $4.1 \mathrm{wt} \%$ of fumed silica and this solution was continuously stirred for $2 \mathrm{~h}$ at $35{ }^{\circ} \mathrm{C}$. An adhesive acrylic spacer, $0.064 \mathrm{~mm}$ wide and $2 \mathrm{~mm}$ thick was applied along the four sides of the photoanode $\left(\mathrm{Ag} / \mathrm{TiO}_{2} / \mathrm{CdS}\right.$ or $\left.\mathrm{Ag} / \mathrm{CdS}\right)$, such that a cavity was created. The gel electrolyte was filled in the cavity carefully using a glass rod. The MWCNT electrode was placed (with the active material side facing the gel) over the photoanode/gel assembly. The assembly was held together using binder clips for $24 \mathrm{~h}$. The clips were removed and the device was ready to use. Fabrication of the photoanode and device is illustrated in Scheme 1.

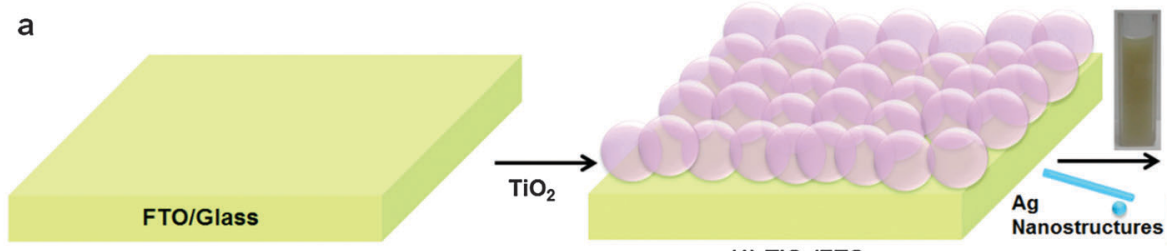

(1) $\mathrm{TiO}_{2} / \mathrm{FTO}$

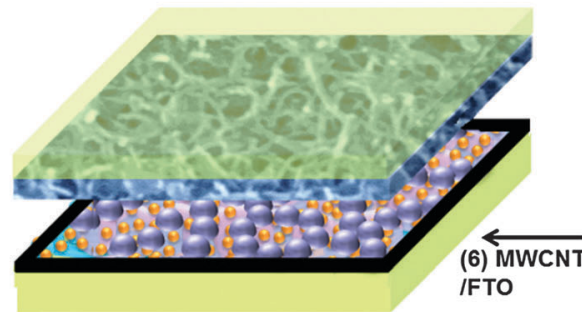

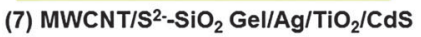

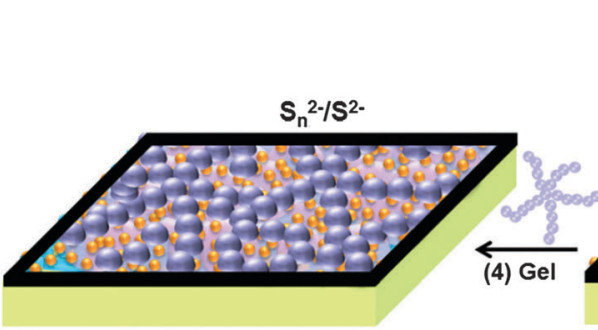

(5) $\mathrm{S}^{2-}-\mathrm{SiO}_{2} \mathrm{Gel} / \mathrm{Ag} / \mathrm{TiO}_{2} / \mathrm{CdS}$

b
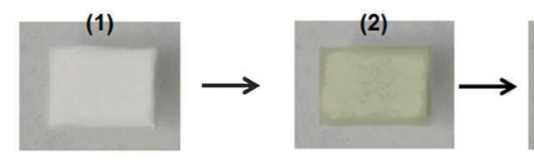

(3)

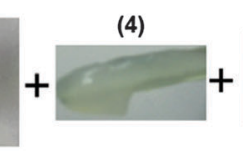

(6)

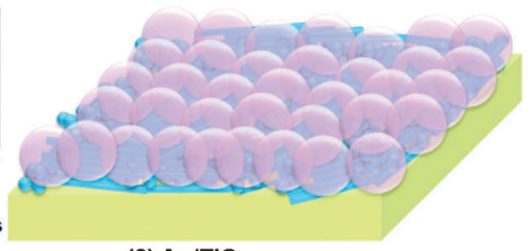

(2) $\mathrm{Ag} / \mathrm{TiO}_{2}$

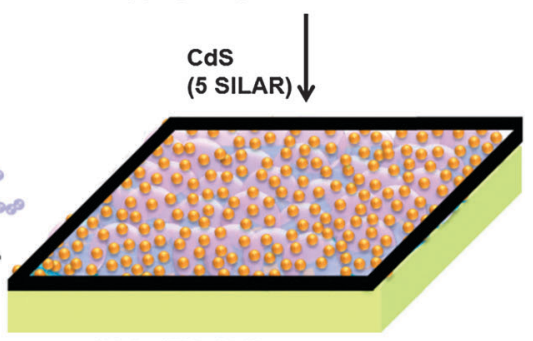

(3) $\mathrm{Ag} / \mathrm{TiO}_{2} / \mathrm{CdS}$

Scheme 1 (a) Preparation of the $\mathrm{Ag} / \mathrm{TiO}_{2} / \mathrm{CdS}$ electrode with $\mathrm{Ag}$ nanostructures and construction of solar cell with a $\mathrm{S}^{2-}$ gel as the electrolyte and a MWCNT/FTO layer as the counter electrode. (b) Photographs represent the state of the electrode after each step. 


\subsection{Characterization techniques}

Surface morphology analysis of Ag products and the electrodes was performed using a field emission scanning electron microscope (Carl Zeiss Supra 40 FE-SEM). HRTEM images of Ag nanostructures and the $\mathrm{Ag} / \mathrm{TiO}_{2} / \mathrm{CdS}$ electrode samples were recorded on a high resolution transmission electron microscope (HRTEM FEI Tecnai G ${ }^{2}$ F30 STWIN with a FEG source operating at $300 \mathrm{kV}$ ). For TEM, a thin layer of $\mathrm{Ag}$ product suspension was carefully transferred onto a carbon coated copper grid of $3.05 \mathrm{~mm}$ diameter and the solvent was evaporated. For the electrode sample, a thin layer was extracted from FTO into water, dispersed in water and then transferred to the grid and water was evaporated. XRD patterns of electrodes or Ag products were recorded on a PANalytical, X'PertPRO instrument with $\mathrm{Cu}-\mathrm{K} \alpha(\lambda=1.5406 \AA)$ radiation. The optical absorption spectra of the films were measured in the diffuse reflectance mode and converted to absorbance using the Kubelka-Munk function and for solutions of $\mathrm{Ag}$ products, spectra were measured in absorbance mode in quartz cuvettes, on a UV-vis-NIR spectrophotometer (Shimadzu UV-3600). Photoluminescence (PL) spectra of films were measured on a Horiba Flouromax- 4 fluorescence spectrometer; a suitable filter was utilized during the measurement and background correction was also applied. The time-correlated single photon counting (TCSPC) method was used for deducing emission lifetimes with a Horiba Jobin Yvon data station HUB functioning in the TCSPC mode. A nano LED diode emitting pulses at $370 \mathrm{~nm}$ with a $1 \mathrm{MHz}$ repetition rate and a pulse duration of $1.3 \mathrm{~ns}$ was employed as an excitation source. Lightscattering Ludox solution (colloidal silica) was used to acquire the instrument response function (prompt). A long pass $500 \mathrm{~nm}$ filter was placed in front of the emission monochromator, for all measurements. The Horiba Jobin Yvon DAS6 fluorescence decay analysis software was used to fit the model function (bi-exponential decays) to the experimental data, with appropriate correction for the instrument response. Current versus potential $(I-V)$ data of QDSCs were measured using a Newport Oriel 3A solar simulator with a Keithley model 2420 digital source meter. A $450 \mathrm{~W}$ xenon arc lamp was the light source which provided a light intensity of $100 \mathrm{~mW} \mathrm{~cm}^{-2}$ of Air Mass (AM) 1.5G illumination; the spatial uniformity of irradiance was confirmed by calibrating with a $2 \mathrm{~cm} \times 2 \mathrm{~cm}$ Si reference cell and re-affirmed with a Newport power meter. Before collection of $I-V$ data, each electrode was allowed to reach equilibrium at opencircuit. EQE versus wavelength data were recorded using a Quantum Efficiency Measurement System, Oriel IQE-200 ${ }^{\mathrm{TM}}$, capable of measurements compliant to ASTM E1021-06. The light source was a $250 \mathrm{~W}$ quartz tungsten halogen lamp, the monochromator path length was $1 / 8 \mathrm{M}$ and the spot size was $1 \mathrm{~mm} \times 2.5 \mathrm{~mm}$ rectangular at focus. Cyclic and/or linear sweep voltammograms (CV and LSV) and electrochemical impedance spectra (EIS) of liquid and gel electrolytes and Ag nanostructures were recorded on an Autolab PGSTAT 302N equipped with a frequency response analyser and a NOVA1.9 software. The CV plots of the electrolytes were recorded at a scan rate of $10 \mathrm{mV} \mathrm{s}^{-1}$ in the potential range of -0.9 to $-0.2 \mathrm{~V}$, in a three electrode cell using two Pt electrodes as working and counter electrodes and a $\mathrm{Ag} / \mathrm{AgCl} / \mathrm{KCl}$ as reference. The LSV and the Nyquist plots of the electrolytes and $\mathrm{Ag}$ nanostructures were obtained by sandwiching the sample between two SS electrodes. A square cavity of $\sim 0.5 \mathrm{~cm}^{2}$ area was constructed using an insulating adhesive foam tape on a SS sheet. The cavity was filled with the sample and another SS sheet was carefully placed over this assembly to complete the cell. Electrical contacts were taken from the SS electrodes, which were prevented from short-circuiting by the thick tape. The thickness of the tape was the thickness of the sample. KPFM was performed on the electrode using a Veeco, Multimode 8 with a ScanAsyst (Nanoscope 8.10 software) microscope. The conductive probe used herein was coated with Pt/Ir on the front and back sides. The probe tip had a radius of $10 \mathrm{~nm}$, a spring constant of $0.2 \mathrm{~N} \mathrm{~cm}^{-2}$, a current sensitivity of $1 \mathrm{nA} \mathrm{V}^{-1}$ and a load force of $50 \mathrm{nN}$ was maintained between the tip and the sample. The sample (Ag nanostructures or $\mathrm{Ag} / \mathrm{TiO}_{2}$ ) deposited on FTO coated glass was affixed on a stainless steel disk with a conducting carbon tape. A thin strip of pin-hole free silver paste was used for making contacts.

\section{Results and discussion}

\subsection{Optimization of the $\mathrm{Ag}$ product}

In the solution phase polyol method, when $\mathrm{AgNO}_{3}$ and PVP are simultaneously injected into the EG formulation, the " $\mathrm{Ag}$ nanoparticles" which are initially formed by reduction of $\mathrm{AgNO}_{3}$ to $\mathrm{Ag}$ by EG, serve as seeds and orchestrate the growth of $\mathrm{Ag}$ nanorods. The role of the coordination agent, PVP, in controlling the evolution of $\mathrm{Ag}$ nanorods, has been established elaborately in previous reports. ${ }^{31,32} \mathrm{PVP}$, in all likelihood, through the $\mathrm{C}=\mathrm{O}$ groups binds to the (111) plane of $\mathrm{Ag}$ more strongly compared to the (200) plane, and as a result, the growth along one crystallographic direction occurs at the expense of the other, and anisotropic structures result. ${ }^{31,32}$ The morphology of the Ag products formed upon reduction, followed by refluxing, are governed by the duration of refluxing at a fixed temperature of $160{ }^{\circ} \mathrm{C}$. Longer the duration of refluxing, greater is the proportion of the $\mathrm{Ag}$ nanorods compared to nanoparticles. The FE-SEM images of Ag products obtained after refluxing at $160{ }^{\circ} \mathrm{C}$ for 20,40 and $60 \mathrm{~min}$, followed by repeated centrifugation at the end of each reflux span, are shown in Fig. 1. The morphology of the product isolated at the end of 20 min reflux time (Fig. 1a and b) comprises of a compactly packed interconnected network of $\mathrm{Ag}$ nanoparticles of irregular shapes with a wide size distribution and a few rod like shapes are seen to be interspersed with the particles. Nanoparticle diameters were found to vary over a wide span of 20 to $180 \mathrm{~nm}$. When the duration of reflux was extended to $40 \mathrm{~min}$ (Fig. 1c and d), the resulting product showed a mixed morphology, as it was composed of bunches of elongated rod like shapes of $\mathrm{Ag}$ juxtaposed with irregular shaped Ag particles, and these nanostructures were observed to be uniformly distributed over multiple length scales. The length of the rods varied from 200 to $1 \mu \mathrm{m}$ and the diameters were found to lie in the range of 15 to $35 \mathrm{~nm}$. Particle dimensions were in the range of $20-80 \mathrm{~nm}$. 


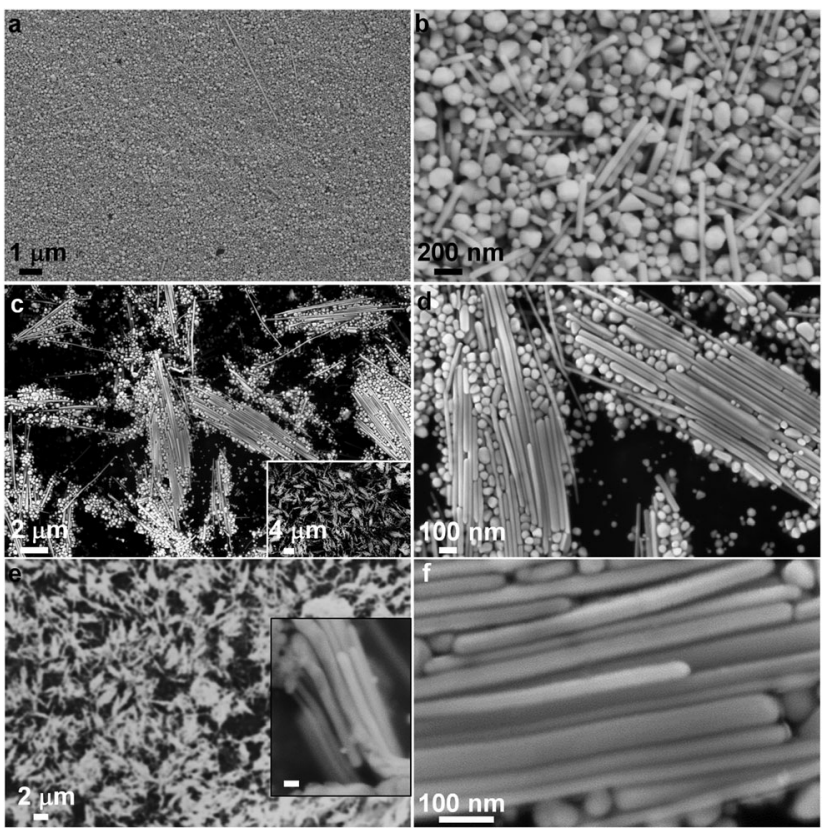

Fig. 1 SEM images of Ag colloids obtained at the end of (a, b) 20, (c, d) 40 and $(\mathrm{e}, \mathrm{f}) 60 \mathrm{~min}$ reflux at $160{ }^{\circ} \mathrm{C}$ of a precursor containing $0.1 \mathrm{M} \mathrm{AgNO}_{3}$ and $264 \mathrm{mg}$ of PVP in EG. Inset of (c) is the corresponding low magnification image of the optimized $\mathrm{Ag}$ product. Scale bar in the inset of (e) corresponds to $50 \mathrm{~nm}$.

Upon further prolonging the reflux time to $60 \mathrm{~min}$ (Fig. 1e and f), the product obtained was predominantly composed of clusters of $\mathrm{Ag}$ nanorods and the proportion of the Ag nanoparticles was sparse, at this juncture. The rod widths varied from 25 to $55 \mathrm{~nm}$; the increase in the rod width compared to the sample obtained after 40 min reflux span could be due to Ostwald ripening. Three photoanodes were constructed with $\mathrm{Ag}$ colloids obtained at the end of 20,40 and 60 min reflux at $160{ }^{\circ} \mathrm{C}$ by integrating each of the $\mathrm{Ag}$ products with a $\mathrm{TiO}_{2} / \mathrm{CdS}$ assembly. The fabrication of the photoanodes was followed using the three electrodes in photoelectrochemical cells with a $0.1 \mathrm{M} \mathrm{Na}_{2} \mathrm{~S}$ solution as the electrolyte and MWCNTs coated FTO/glass as the counter electrode. Surprisingly, the photoanode encompassing the Ag product with a mixed morphology of nanorods and nanoparticles (which was obtained at the end of $40 \mathrm{~min}$ reflux at $160{ }^{\circ} \mathrm{C}$ ), gave, reproducibly, the best solar cell performance compared to the $\mathrm{Ag}$ nanoparticles $(20 \mathrm{~min})$ and $\mathrm{Ag}$ nanorods (60 min) (Fig. S1 and Table S1, ESI $\dagger$ ). Since the Ag colloid with mixed morphology delivered the highest power conversion efficiency (PCE), electrodes based on this product, labeled as "Ag nanostructures" were studied in detail, in the following sections. The low and high magnification FE-SEM images of $\mathrm{TiO}_{2}, \mathrm{Ag} / \mathrm{TiO}_{2}$ and $\mathrm{Ag} / \mathrm{TiO}_{2} / \mathrm{CdS}$ electrodes are shown in Fig. S2 (ESI $\dagger$ ). The morphologies of $\mathrm{TiO}_{2}$ and $\mathrm{Ag} / \mathrm{TiO}_{2} / \mathrm{CdS}$ are similar. The films are composed of irregular shaped particles, characteristic of $\mathrm{TiO}_{2}$ and CdS, respectively, and the signature morphology of $\mathrm{Ag}$ nanostructures, i.e., a fibrillar texture is only seen in the images of $\mathrm{Ag} / \mathrm{TiO}_{2}$. The $\mathrm{Ag} / \mathrm{TiO}_{2} / \mathrm{CdS}$ assembly comprises of interlinked particles, separated by pores of 50 to $200 \mathrm{~nm}$ in dimensions.

\subsection{Structure and conduction of $\mathrm{Ag}$ nanostructures}

The TEM image of $\mathrm{Ag}$ nanostructures (optimized on the basis of solar cell performance) obtained after refluxing the precursor solution for $40 \mathrm{~min}$ is shown in Fig. 2a. Distinctive nanorod like shapes and nanoparticles of Ag are clearly seen (Fig. 2a). The rods have widths in the range of 15 to $35 \mathrm{~nm}$, which is in line with the FE-SEM results, and the maximum length of the rods is about $1 \mu \mathrm{m}$. Fig. $2 \mathrm{~b}$ shows the lattice scale images for the $\mathrm{Ag}$ nanoparticles, the particles are composed of nanocrystallites, and the fringe spacing from one such entity is observed to be $0.23 \mathrm{~nm}$, which matches with the (111) plane of the face centered cubic (fcc) lattice of Ag (JCPDS: 04-783). Fig. 2c shows the HRTEM image of an Ag nanorod, the inter-fringe separation is $\sim 0.24 \mathrm{~nm}$, which concurs with the (111) plane facet of Ag. The (111) plane is observed to be perpendicular to its growth axis, which is typical of Ag nanowires grown by a polyol method with PVP as a structure directing agent. ${ }^{32}$ The selected area electron diffraction (SAED) pattern (Fig. 2d), extracted from a section of the Ag nanorod, shows bright spots, indicating the crystallinity of the samples and the spots could be indexed with the fcc crystal structure of $\mathrm{Ag}$ with a lattice constant of $4.07 \AA$. The TEM image of the $\mathrm{Ag} / \mathrm{TiO}_{2} / \mathrm{CdS}$ assembly (Fig. 2e) shows

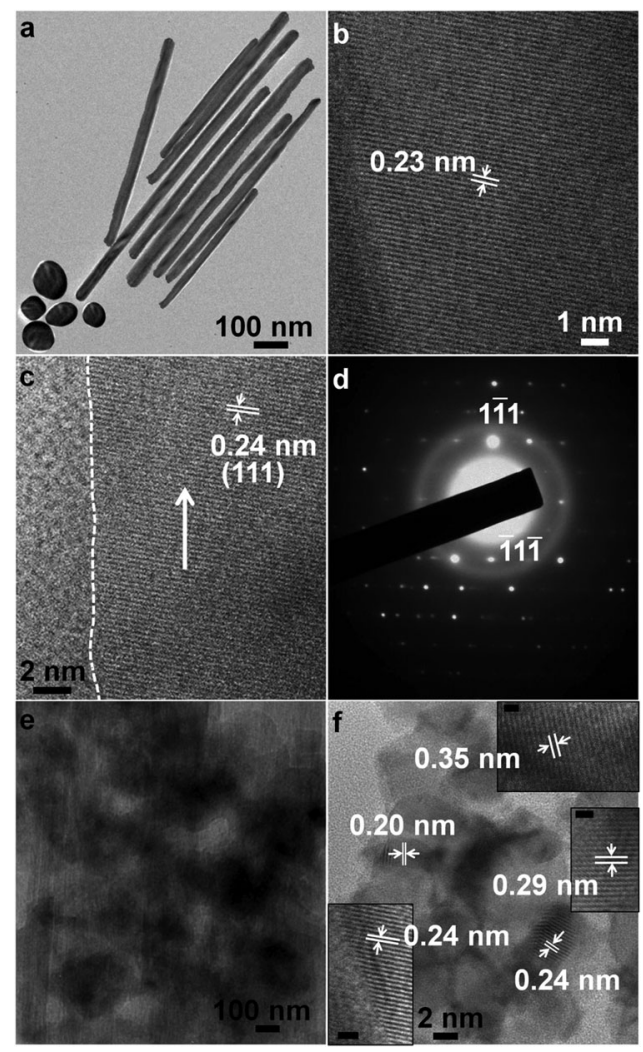

Fig. 2 (a) TEM image of Ag nanostructures (obtained after 40 min reflux span), the corresponding lattice scale images of (b) Ag nanoparticles and (c) Ag nanorods, (d) SAED pattern from an Ag nanorod, (e) bright field image of the $\mathrm{Ag} / \mathrm{TiO}_{2} / \mathrm{CdS}$ photoanode and $(\mathrm{f})$ the corresponding lattice scale image. Top-, middle- and bottom-insets in (f) correspond to $\mathrm{TiO}_{2}, \mathrm{CdS}$ and $\mathrm{Ag}$ respectively. The dimensions of the solid lines shown in the top-, middle- and bottom-insets of ( $\mathrm{f}$ ) are $1 \mathrm{~nm}$. 

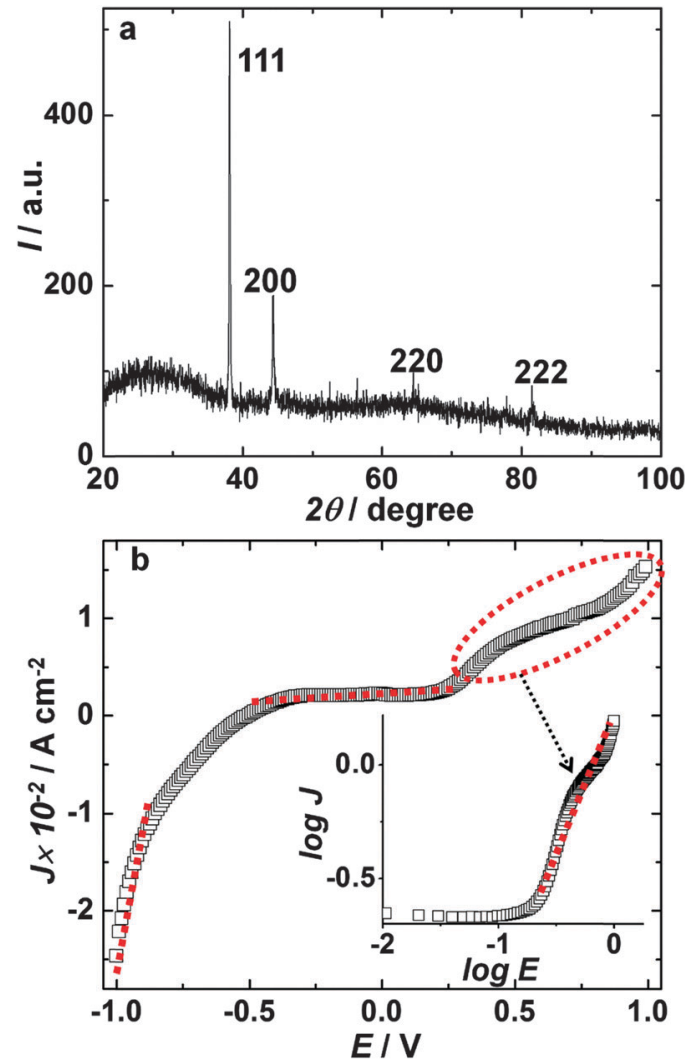

Fig. 3 (a) XRD pattern of Ag nanostructures and (b) $J-V$ characteristics of $\mathrm{Ag}$ nanostructures and inset shows the corresponding $\log \mathrm{J}$ versus $\log \mathrm{V}$ plot. The dotted lines are the linear fits.

interconnected irregular shaped particles, primarily, $\mathrm{TiO}_{2}$ and CdS based, and elongated shapes are also seen, which originate from Ag nanorods. The corresponding HRTEM image (Fig. 2f) shows lattice fringes from all the three components, indicating the formation of the ternary photoanode. A fringe spacing of $0.35 \mathrm{~nm}$ aligns with the (101) facet of anatase $\mathrm{TiO}_{2}$ with a body centered tetragonal lattice (JCPDS: 89-4921), inter-fringe separations of: $0.29 \mathrm{~nm}$ corresponds to the (200) plane of the fcc structure of CdS (JCPDS: 652887) and $0.24 \mathrm{~nm}$ agrees with the (111) plane of Ag with a fcc structure. The fringe separation of $0.20 \mathrm{~nm}$ matches with the 200 reflection of Ag.

The XRD pattern of the Ag nanostructures is shown in Fig. 3. The diffractogram shows one strong intense peak at $2.35 \AA$, and lower intensity peaks at 2.04, 1.44 and $1.18 \AA$, which concur well with $d$ values of the face centered cubic lattice of Ag (JCPDS: 04-0783) corresponding to the (111), (200), (220) and (222) planes. The higher intensity of the diffraction peak observed at $2 \theta=38.3^{\circ}$ also agrees with the preferred orientation along the (111) plane, which is responsible for the formation of elongated structures. The linear sweep voltammogram of $\mathrm{Ag}$ nanostructures, recorded between two Pt electrodes, in a sandwich configuration, at a scan rate of $20 \mathrm{mV} \mathrm{s}^{-1}$, is shown in Fig. 3b. The $J$ (current density) versus applied potential $(E$ or $V)$ was linear in the potential regimes of -1.0 to $-0.8 \mathrm{~V}$ and -0.5 to $+0.25 \mathrm{~V}$. The slopes of the linear fits $(J / V)$ in these regimes of the $J-V$ plot, wherein the $J-V$ dependences are almost ohmic, are equivalent to the dc resistances offered by Ag nanostructures to the flow of electrons. The average conductivity $(\sigma)$ of $\mathrm{Ag}$ nanostructures was deduced from the slopes, using eqn (1).

$$
\begin{aligned}
\sigma\left(\mathrm{S} \mathrm{cm}^{-1}\right)= & J / V\left(\text { slope, } \mathrm{A} \mathrm{cm}^{-2} \mathrm{~V}^{-1}\right) \\
& \times d(\text { distance between the electrodes, } \mathrm{cm})
\end{aligned}
$$

The conductivity was deduced to be $1.26 \times 10^{-2} \mathrm{~S} \mathrm{~cm}^{-1}$. The $J-V$ dependence of $\mathrm{Ag}$ nanostructures was non-linear in the +0.25 to $+1.0 \mathrm{~V}$ range, and the data in this range could be fitted into a Mott-Gurney model. The current-voltage dependence in this potential range is space-charge limited, as per the MottGurney law, shown in eqn (2).

$$
J=9 / 8 \varepsilon \varepsilon_{0} \mu V^{2} / d^{3}
$$

In eqn (2), $J$ is the current density, $\varepsilon$ is the relative dielectric constant of the active layer, $\varepsilon_{0}$ is the permittivity of free space, $\mu$ is the charge carrier mobility, $V$ is the applied voltage, and $d$ is the distance between the electrodes. A slope of 2 , as dictated by eqn (2) for a plot of $\log J$ versus $\log V$, implies that a space charge limited current (SCLC) flows in the said potential regime of +0.25 to $+1.0 \mathrm{~V}$. The observed slope was $\sim 1.8$, which is close to 2 . The $J-V$ data analysis affirms the ability of $\mathrm{Ag}$ nanostructures to function as electron acceptors.

\subsection{Photo-physical properties and energetics}

The absorption spectra of the Ag nanostructures' colloid and electrodes of neat $\mathrm{CdS}, \mathrm{TiO}_{2} / \mathrm{CdS}$ and $\mathrm{Ag} / \mathrm{TiO}_{2} / \mathrm{CdS}$ are shown in Fig. 4a. The Ag nanostructures show a broad absorption peak in the visible region with $\lambda_{\max }$ at $420 \mathrm{~nm}$, followed by another narrow peak in the near infrared (NIR) region with a $\lambda_{\max }=972 \mathrm{~nm}$. The peak at $420 \mathrm{~nm}$ arises from the transverse mode of Ag nanorods and from the nanoparticles less than $50 \mathrm{~nm}$ in size. Bulk silver shows plasmonic resonance at $350 \mathrm{~nm}$, and for nano-sized Ag, this peak is red-shifted. ${ }^{33}$ The longitudinal mode of the plasmons produces the peak at $972 \mathrm{~nm}$. The presence of both longitudinal and transverse modes (corresponding to length and breadth) complies with the formation of a mixed morphology of rods and particles. Both neat $\mathrm{CdS}$ and $\mathrm{TiO}_{2} / \mathrm{CdS}$ films exhibit a broad absorption peak in the 400 to $500 \mathrm{~nm}$ range, corresponding to electronic transitions in the band gap which is in concordance with the absorption data reported for CdS QDs. ${ }^{34} \mathrm{The} \mathrm{Ag} / \mathrm{TiO}_{2}$ film showed no distinctive peak in the visible region, but in the NIR region, the longitudinal plasmonic peak of $\mathrm{Ag}$ was observed. Upon comparing the absorption of $\mathrm{TiO}_{2} / \mathrm{CdS}$ and $\mathrm{Ag} / \mathrm{TiO}_{2}$ with that of $\mathrm{Ag} / \mathrm{TiO}_{2} / \mathrm{CdS}$, we find that the absorption of the latter is enhanced compared to that of $\mathrm{TiO}_{2} / \mathrm{CdS}$ and $\mathrm{Ag} / \mathrm{TiO}_{2}$, in the entire spectral range under consideration. Particularly, the $\mathrm{Ag} / \mathrm{TiO}_{2} / \mathrm{CdS}$ film shows a broad absorption in the 400 to $500 \mathrm{~nm}$ range, increased in intensity compared to $\mathrm{TiO}_{2} / \mathrm{CdS}$ indicating the role of $\mathrm{Ag}$ nanostructures in increasing the absorption of CdS QDs. The near field surface plasmon excitation of the transverse modes of the $\mathrm{Ag}$ nanorods (NRs) and Ag NPs of less than $50 \mathrm{~nm}$ dimensions increase the absorption of the CdS QDs. This effect is coupled with the increased light scattering induced by the longitudinal mode of the rods and the larger sized Ag nanoparticles, which 

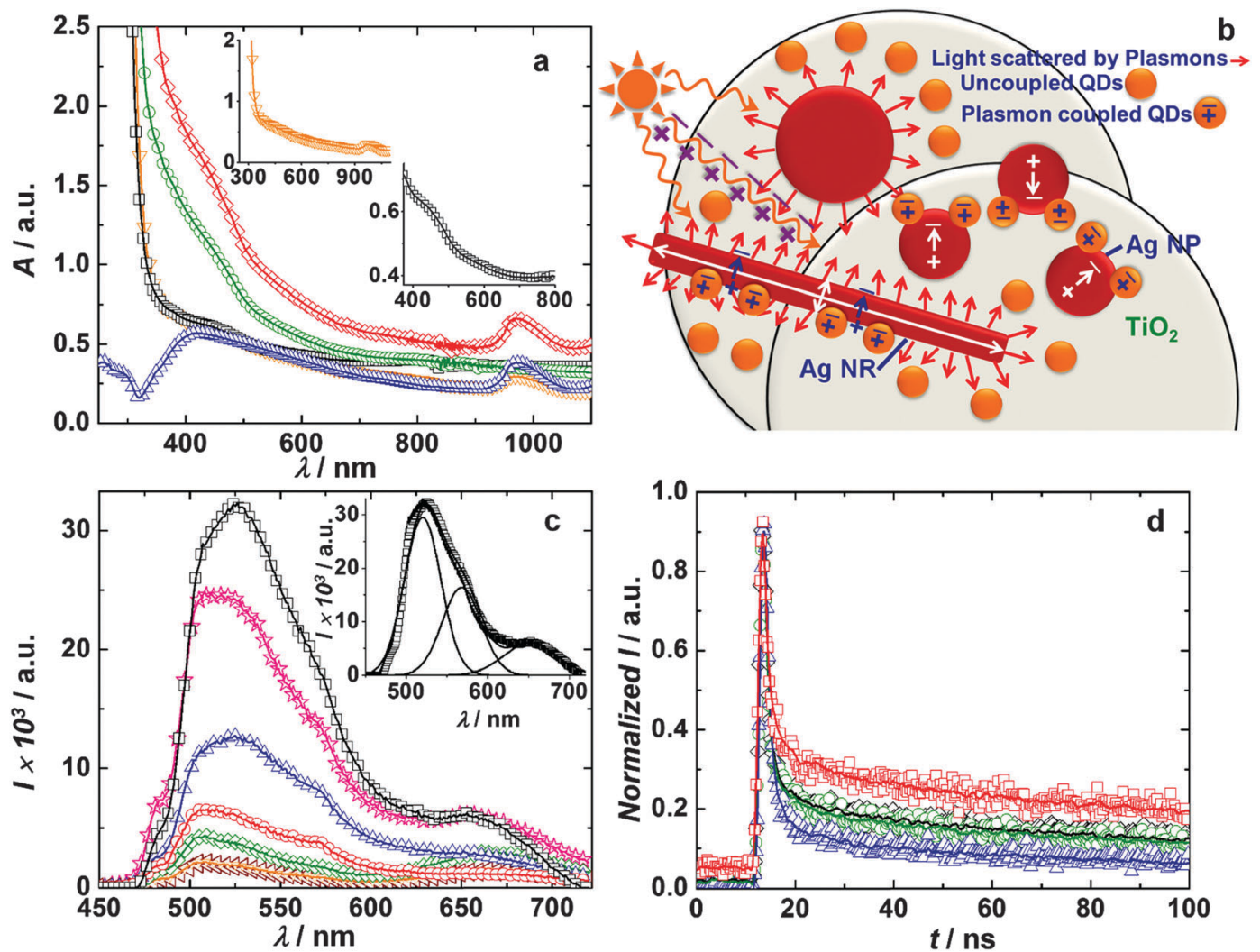

Fig. 4 Absorption spectra of (a) Ag nanostructure colloid $(\triangle)$, neat $\mathrm{CdS}(\square), \mathrm{TiO}_{2} / \mathrm{CdS}(O), \mathrm{Ag} / \mathrm{TiO}_{2}(\nabla)$ and $\mathrm{Ag} / \mathrm{TiO} / 2 / \mathrm{CdS}(\diamond)$, (b) a schematic of plasmonic and light scattering effects induced by $\mathrm{Ag}$ nanostructures in the $\mathrm{Ag} / \mathrm{TiO}_{2} / \mathrm{CdS}$ assembly, (c) fluorescence spectra of CdS QDs on

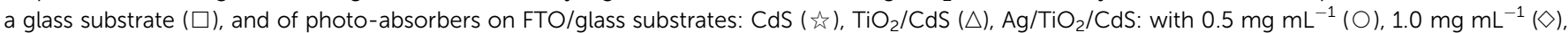
$1.8 \mathrm{mg} \mathrm{mL}^{-1}(\nabla)$ and $2.5 \mathrm{mg} \mathrm{mL}^{-1}(\triangleleft)$ Ag product concentrations in a $1: 1 \mathrm{v} / \mathrm{v}$ ratio of toluene and ultrapure water and (d) time resolved fluorescence decay traces of (a) CdS QDs/glass ( $\square$ ) and of photo-absorbers on FTO/glass substrates: $\mathrm{CdS}(\diamond), \mathrm{TiO}_{2} / \mathrm{CdS}(O)$ and $\mathrm{Ag} / \mathrm{TiO} \mathrm{O}_{2} / \mathrm{CdS}(\triangle)($ with $\mathrm{Ag}$ concentration of $\left.1.8 \mathrm{~mL} \mathrm{~mL}{ }^{-1}\right)$. $\left(\lambda_{\mathrm{ex}}=370 \mathrm{~nm}\right.$ and $\left.\lambda_{\mathrm{em}}=520 \mathrm{~nm}\right)$. Insets of (a) are enlarged views of the absorption spectra of neat $\mathrm{CdS}(\square)$ and $\mathrm{Ag} / \mathrm{TiO} \mathrm{O}_{2}(\nabla)$. Inset of $(\mathrm{b})$ is the deconvoluted emission spectrum of CdS QDs/glass ( $\square$ ); the solid lines represent the three fitted components.

also contribute to enhanced light absorption by the CdS QDs. These two effects work in harmony to yield improved photoconversion efficiencies for the plasmonic electrode, as shown in the schematic in Fig. $4 \mathrm{~b}$. An intense absorption peak is also observed at $\sim 969 \mathrm{~nm}$, blue shifted by $5 \mathrm{~nm}$, compared to neat $\mathrm{Ag}$ nanostructures. Since the increment in absorption for the $\mathrm{Ag} / \mathrm{TiO}_{2} / \mathrm{CdS}$ film was observed in the complete spectral range, the increase in the absorption of the CdS QDs via near field effects or localized surface plasmon resonance cannot be ruled out. The $\mathrm{TiO}_{2}$ layer is highly porous; CdS QDs percolate through the cross-section of $\mathrm{TiO}_{2}$, and they are also located in the vicinity of the plasmonic Ag nanostructures, as a consequence, a near-field enhancement of the photo-carrier generation rate is possible. Light scattering by $\mathrm{Ag}$ nanostructures, in particular by the $\mathrm{Ag}$ nanorods, is one of the primary reasons for enhanced absorption of the CdS sensitized electrodes, which translates to increased external quantum efficiency especially at longer wavelengths. Furthermore, the ability of Ag nanostructures to accept electrons due to a favorable energy level offsets with respect to the conduction band of CdS, also facilitates electron transfer, which again can lead to higher photocurrents, as discussed below.
In the $\mathrm{Ag} / \mathrm{TiO}_{2} / \mathrm{CdS}$ assembly, the semiconductor (such as $\mathrm{TiO}_{2}$ ) and metal nanoparticles (such as Ag nanorod or nanoparticle) are in direct contact. A metal (Ag)-semiconductor $\left(\mathrm{TiO}_{2}\right)$ contact is formed, and the Fermi level of $\mathrm{Ag}$ will shift to more negative potentials (versus $\mathrm{NHE}$ ), and come close to a position just below the $\mathrm{CB}$ of $\mathrm{TiO}_{2}$ and is designated as the apparent Fermi level. ${ }^{35}$ Upon illumination, in the $\mathrm{Ag} / \mathrm{TiO}_{2} / \mathrm{CdS}$ electrode, the photoexcited electrons, from the CB of CdS QDs, which is positioned at $3.61 \mathrm{eV}$, will flow to $\mathrm{TiO}_{2}$, and from $\mathrm{TiO}_{2}$ to Ag (vis-à-vis equilibrated Fermi levels, the apparent Fermi level $\left(E_{\mathrm{F}}{ }^{\prime}=4.2 \mathrm{eV}\right)$.) and then to FTO, for which the work function is $4.7 \mathrm{eV}$. While the $\mathrm{VB}$ and $\mathrm{CB}$ positions of $\mathrm{TiO}_{2}$ and CdS QDs are known, ${ }^{36}$ the unknown (i) work function of $\mathrm{Ag}$ nanostructures and (ii) the equilibrated Fermi level of the $\mathrm{Ag} / \mathrm{TiO}_{2}$ assembly were determined by performing Kelvin probe force microscopy (KPFM) measurements on electrodes of the same type. In KPFM, the topography of the film surface is measured in tapping mode and the surface potential variation is measured using a conducting tip. The topographies and the corresponding surface potential maps of the $\mathrm{Ag}$ nanostructures and the $\mathrm{FTO} / \mathrm{Ag} / \mathrm{TiO}_{2}$ electrodes are shown in Fig. 5. The tip was held at $\sim 100 \mathrm{~nm}$ above the film surface, and it is charged due 
to the applied ac potential. The sample surface is also charged since it is in the vicinity of the charged tip. An ac bias is applied to a conducting Pt/Ir tip of a known work function, it scans the sample surface and the localized contact potential difference $\left(V_{\mathrm{CPD}}\right)$ that arises between the conducting tip and the sample surface is used for generating the surface potential map, as shown in the following equation.

$$
V_{\mathrm{CPD}}=\left(\Phi_{\text {tip }}-\Phi_{\text {sample }}\right) / \mathrm{e}^{-}
$$

$\Phi_{\text {tip }}$ is the work function of the conducting Pt/Ir coated Si cantilever and $\Phi_{\text {sample }}$ is the work function of the sample, i.e., the Ag nanostructures or the $\mathrm{Ag} / \mathrm{TiO}_{2}$ electrode. The work function of the $\mathrm{Pt} / \mathrm{Ir}$ tip was first calibrated with highly ordered pyrolytic graphite $(\mathrm{HOPG})\left(\Phi_{\mathrm{HOPG}}=4.6 \mathrm{eV}\right)$ to convert the measured $V_{\mathrm{CPD}}$ to absolute surface work function. The absolute surface work function of the sample was calculated using eqn (4).

$$
\Phi_{\text {sample }}=4.6 \mathrm{eV}+V_{\mathrm{CPD} \mathrm{HOPG}}-V_{\mathrm{CPD} \text { sample }}
$$

$\Phi_{\text {tip }}$ is the work function of the conducting Pt/Ir coated Si cantilever and it is about $5.5 \mathrm{eV}$ and $\Phi_{\text {sample }}$ is the work function of the sample. The surface potential of the $\mathrm{Ag}$ nanostructure electrode was $600 \mathrm{mV}$ and the work function of this electrode was deduced to be $4.4 \mathrm{eV}$. The surface potential of the $\mathrm{Ag} / \mathrm{TiO}_{2}$ assembly was $800 \mathrm{mV}$ and the corresponding work function which can be approximated to the equilibrated Fermi level was calculated to be $4.2 \mathrm{eV}$. The energy band diagram (Fig. 5) illustrates this dominant excited electron deactivation pathway, from the CB of CdS to the equilibrated Fermi level. The ability of $\mathrm{Ag}$ nanostructures to serve as effective electron acceptors can also aid in suppressing electron-hole recombination, as injected carriers are driven to FTO, instead of the electrolyte.

To establish the photo-excited electron relay in the $\mathrm{Ag} / \mathrm{TiO}_{2} /$ CdS electrode, fluorescence and emission decay measurements were done. The fluorescence spectra of neat CdS QDs deposited on glass and FTO/glass, $\mathrm{TiO}_{2} / \mathrm{CdS}$ and $\mathrm{Ag} / \mathrm{TiO}_{2} / \mathrm{CdS}$ electrodes were recorded at a fixed excitation wavelength of $370 \mathrm{~nm}$ (Fig. 4c). Neat CdS QDs (deposited on glass) show a broad asymmetric emission peak, centered at $\sim 525 \mathrm{~nm}$. This peak was deconvoluted into three components with peak maxima at 520, 568 and $652 \mathrm{~nm}$; the high intensity peak is attributed to radiative band edge recombination and the lower intensity peaks are due to electron trapping in surface states. Further confirmation for existence of trap states was obtained in the form of two distinct excited electron lifetime components which were deduced from emission decay analyses. The emission intensity of neat CdS quenched on going to FTO/CdS and $\mathrm{TiO}_{2} / \mathrm{CdS}$, by $\sim 25$ and $60.5 \%$ respectively, due to electron transfer from the $\mathrm{CB}$ of $\mathrm{CdS}$ to FTO in FTO/CdS and from CB of CdS to $\mathrm{TiO}_{2}$ in $\mathrm{TiO}_{2} / \mathrm{CdS}$ electrodes. Further emission quenching occurred upon incorporation of $\mathrm{Ag}$ nanostructures (1.8 $\mathrm{mg} \mathrm{mL}^{-1}$ colloid strength) in the $\mathrm{TiO}_{2} / \mathrm{CdS}$ assembly, suggestive of improved charge transfer to the current collector, facilitated by $\mathrm{Ag}$ nanostructures. The extent of quenching showed a systematic increase as a function
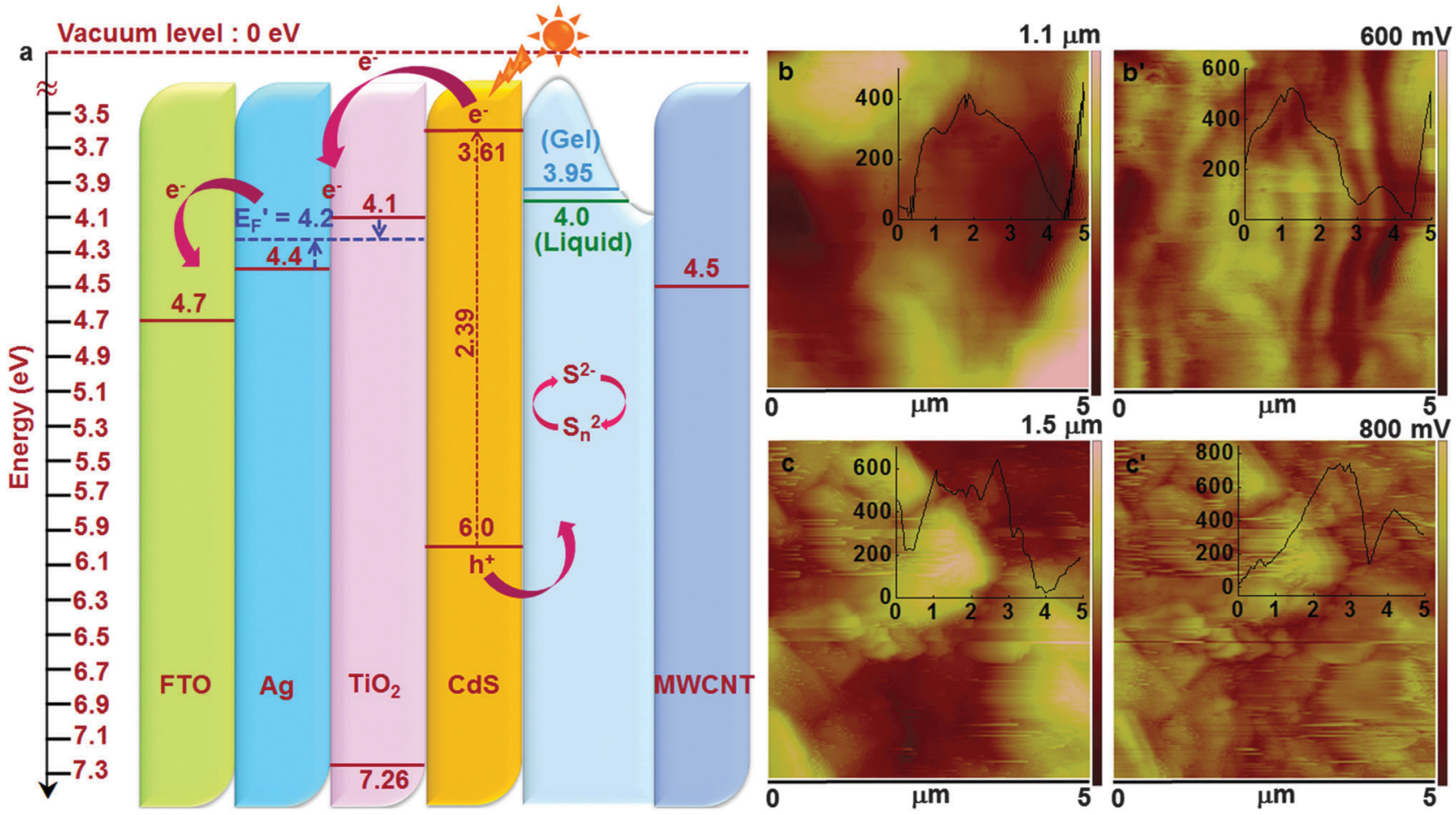

Fig. 5 (a) Energy band diagram illustrating all possible electron transfer modes in the $\mathrm{FTO} / \mathrm{Ag} / \mathrm{TiO}_{2} / \mathrm{CdS}$ assembly; the horizontal dashed line shows the equilibrated Fermi level $\left(E_{\mathrm{F}}{ }^{\prime}\right)$ position obtained from KPFM. Topography $(\mathrm{b}, \mathrm{c})$ and surface potential $\left(\mathrm{b}^{\prime}, \mathrm{c}^{\prime}\right)$ maps of the Ag nanostructures and the $\mathrm{FTO} / \mathrm{Ag} / \mathrm{TiO}_{2}$ electrode recorded over scanned areas of $5 \mu \mathrm{m} \times 5 \mu \mathrm{m}$. Corresponding cross-sectional profiles taken along the middle of the images are shown as insets. 
of increasing colloid strength of $\mathrm{Ag}$ nanostructures (from $0.5 \mathrm{mg} \mathrm{mL} \mathrm{m}^{-1}$ to $1.8 \mathrm{mg} \mathrm{mL}^{-1}$ ); it plummeted by 81 to $94 \%$ of the original luminescence of CdS. Upon further raising the $\mathrm{Ag}$ nanostructures' concentration to $2.5 \mathrm{mg} \mathrm{mL}^{-1}$, the quenching saturated, indicating that maximum charge transfer occurs at $1.8 \mathrm{mg} \mathrm{mL}{ }^{-1}$ concentration. The concentration of $\mathrm{Ag}$ nanostructures was optimum at $1.8 \mathrm{mg} \mathrm{mL}^{-1}$ colloid strength, and this concentration was used for solar cell fabrication as well.

Time resolved emission decay measurements were done to confirm the mechanism of electron transfer in the $\mathrm{Ag} / \mathrm{TiO}_{2} / \mathrm{CdS}$ assembly. The fluorescence decay curves of the electrodes: CdS QDS on glass and on $\mathrm{FTO}, \mathrm{TiO}_{2} / \mathrm{CdS}$ and $\mathrm{Ag} / \mathrm{TiO}_{2} / \mathrm{CdS}\left(\lambda_{\mathrm{ex}}=370 \mathrm{~nm}\right.$ and $\lambda_{\mathrm{em}}=520 \mathrm{~nm}$ ) are displayed in Fig. $4 \mathrm{~d}$. The fluorescence data were fitted to bi-exponential curves on the basis of $\chi^{2}$ values and the plots of the residuals and fitted parameters are summarized in Table 1 . In eqn (5) and (6), $\tau_{\mathrm{i}}$ and $B_{\mathrm{i}}$ are the decay time constants and amplitudes, respectively, of the individual decay components and $\langle\tau\rangle$ is the average electron lifetime.

$$
\begin{aligned}
& f(t)=B_{1} \mathrm{e}^{-t / \tau_{1}}+B_{2} \mathrm{e}^{-t / \tau_{2}} \\
& \langle\tau\rangle=\sum_{\mathrm{i}} B_{\mathrm{i}} \tau_{\mathrm{i}}^{2} / \sum_{\mathrm{i}} B_{\mathrm{i}} \tau_{\mathrm{i}}
\end{aligned}
$$

For pristine CdS QDs deposited on glass, the average electron lifetime is $18.2 \mathrm{~ns}$, which includes a long-lived component of $18.5 \mathrm{~ns}$ originating from band edge recombination and the short-lived component of 0.24 ns due to electron trapping in the surface states. The latter phenomenon typically occurs on a time scale of $<100 \mathrm{ps}^{37}$ For $\mathrm{CdS} /$ glass, there is no electron injection, as glass is electrically insulating. For CdS/FTO, the average lifetime reduced to $13.17 \mathrm{~ns}$ (due to electron injection from QDs to FTO) and for the $\mathrm{TiO}_{2} / \mathrm{CdS}$ electrode, it further decreased to $3.397 \mathrm{~ns}$. In the latter electrode, the fast and slow components of $0.209 \mathrm{~ns}$ and $3.85 \mathrm{~ns}$, respectively, are ascribed to electron transfer from CdS QDs in intimate contact with $\mathrm{TiO}_{2}$ and from CdS QDs which are not directly anchored to $\mathrm{TiO}_{2}$ and have to surmount QD-QD grain boundaries to reach $\mathrm{TiO}_{2}$. Upon including $\mathrm{Ag}$ nanostructures in the $\mathrm{TiO}_{2} / \mathrm{CdS}$ assembly, the average electron lifetime in the $\mathrm{Ag} / \mathrm{TiO}_{2} / \mathrm{CdS}$ electrode was $0.65 \mathrm{~ns}$, with short- and long-lived components of 0.32 and 1.39 ns. The ability of $\mathrm{Ag}$ nanostructures to serve as electron acceptors, and the favorably poised apparent Fermi level of $\mathrm{Ag} / \mathrm{TiO}_{2}$, causes rapid electron injection from the $\mathrm{CB}$ of $\mathrm{CdS}$ QDs to the $E_{\mathrm{F}}{ }^{\prime}$ at $4.2 \mathrm{eV}$ in $\mathrm{Ag} / \mathrm{TiO}_{2}$. The energy level gradient of $E_{\mathrm{CB}(\mathrm{CdS})}-E_{\mathrm{F}}{ }^{\prime}\left(\mathrm{Ag} / \mathrm{TiO}_{2}\right)=0.59 \mathrm{eV}$ in $\mathrm{Ag} / \mathrm{TiO}_{2} / \mathrm{CdS}$ is higher than

Table 1 Kinetic parameters of emission decay analysis of photosensitizer films deduced from double exponential fits ${ }^{a}$

\begin{tabular}{llccccc}
\hline Sample & $B_{1}$ & $\tau_{1}(\mathrm{~ns})$ & $B_{2}$ & $\tau_{2}(\mathrm{~ns})$ & $\langle\tau\rangle(\mathrm{ns})$ & $\chi^{2}$ \\
\hline Glass/CdS & 56.65 & 0.238 & 43.35 & 18.5 & 18.1981 & 1.07 \\
$\mathrm{FTO} / \mathrm{CdS}$ & 57.73 & 13.3 & 42.27 & 0.18 & 13.1716 & 1.04 \\
$\mathrm{TiO}_{2} / \mathrm{CdS}$ & 27.66 & 3.85 & 72.34 & 0.209 & 3.397 & 1.01 \\
$\mathrm{Ag}_{\mathrm{TiO}} / \mathrm{CdS}$ & 90.57 & 0.324 & 9.43 & 1.39 & 0.6531 & 0.87
\end{tabular}

${ }^{a} B$ is the relative amplitude of each lifetime, $\tau_{1}$ and $\tau_{2}$ are the components of fluorescence lifetime and $\chi^{2}$ denotes the fit quality. the gradient that prevails in the absence of $\mathrm{Ag}$ nanostructures $\left(E_{\mathrm{CB}(\mathrm{CdS})}-E_{\mathrm{CB}\left(\mathrm{TiO}_{2}\right)}=0.49 \mathrm{eV}\right)$ in the $\mathrm{TiO}_{2} / \mathrm{CdS}$ electrode. Steeper the energy level offset between the sensitizer's $\mathrm{CB}$ and the acceptor's $E_{\mathrm{F}}$ or $\mathrm{CB}$, greater is the driving force for electron transfer. ${ }^{38}$ The large electronic conductivity of Ag nanostructures also permits fast electron propagation. Another advantage of the electron accepting capability of $\mathrm{Ag}$ nanostructures is the suppression of back electron transfer. Cumulatively, these attributes of $\mathrm{Ag}$ nanostructures can increase both photovoltage and photocurrent, when the $\mathrm{Ag} / \mathrm{TiO}_{2} / \mathrm{CdS}$ electrode is used in a solar cell.

To determine the electron injection rates in the $\mathrm{TiO}_{2} / \mathrm{CdS}$ and $\mathrm{Ag} / \mathrm{TiO}_{2} / \mathrm{CdS}$ electrodes, the average emission lifetimes were used which are inclusive of both slow and fast decay components. The rates of electron transfer were obtained from the following expressions.

$$
\begin{gathered}
k=1 /\langle\tau\rangle\left(\mathrm{TiO}_{2} / \mathrm{CdS}\right)-1 /\langle\tau\rangle(\mathrm{FTO} / \mathrm{CdS}) \\
k=1 /\langle\tau\rangle\left(\mathrm{Ag} / \mathrm{TiO}_{2} / \mathrm{CdS}\right)-1 /\langle\tau\rangle\left(\mathrm{TiO}_{2} / \mathrm{CdS}\right)
\end{gathered}
$$

The apparent electron transfer rate $(k)$ from $\mathrm{CdS}$ to $\mathrm{Ag} / \mathrm{TiO}_{2}$ was deduced to be $1.24 \times 10^{9} \mathrm{~s}^{-1}$, which is much faster than the kinetics of electron injection in the electrode devoid of $\mathrm{Ag}$ nanostructures, wherein a $k=0.22 \times 10^{9} \mathrm{~s}^{-1}$ was observed. The electron transfer rate was 5.6 times faster, in the presence of $\mathrm{Ag}$ nanostructures. These values are in agreement with the reported values for electron injection rates in the range of $10^{8}$ to $10^{9} \mathrm{~s}^{-1}$ reported for $\mathrm{QD} / \mathrm{TiO}_{2}$ systems. ${ }^{13}$ The evidence of rapid electron injection kinetics in the $\mathrm{Ag} / \mathrm{TiO}_{2} / \mathrm{CdS}$ electrode reaffirms the efficacy of Ag nanostructures in collecting photo-excited electrons, and this can translate to high photocurrents.

\subsection{Liquid versus gel electrolyte}

Photoelectrochemical cells were constructed using $\mathrm{TiO}_{2} / \mathrm{CdS}$ and $\mathrm{Ag} / \mathrm{TiO}_{2} / \mathrm{CdS}$ electrodes as photoanodes and MWCNTs coated FTO/glass as a counter electrode. The electrolyte was $0.1 \mathrm{M} \mathrm{Na}_{2} \mathrm{~S}$ dissolved in a solution of $3: 7 \mathrm{v} / \mathrm{v}$ ratio of deionized water to methanol. A gel electrolyte was also prepared by dispersing fumed silica $(4.1 \mathrm{wt} \%)$ in the liquid electrolyte and quasi solid state cells with the gel sandwiched between the photoanode and MWCNTs were fabricated. But prior to examining the photoactivity of the gel based cells, the electrical properties of the gel were compared with that of the liquid electrolyte. The $I-V$ characteristics and Nyquist plots ( $Z^{\prime \prime}$ versus $Z^{\prime}$ ) of liquid and gel electrolytes recorded in a $\mathrm{Pt} / \mathrm{gel}$ or liquid/Pt configuration are shown in Fig. 6a and b. The potential window of a linear (akin to a plateau-like) response ascribable to an ohmic dependence of voltage on current is found between -0.25 and $+0.30 \mathrm{~V}$ for both liquid and gel electrolytes. The electronic conductivities $(\sigma)$ of liquid and gel electrolyte films were calculated using eqn (1), and were calculated to be $0.94 \times 10^{-2}$ and $1.07 \times 10^{-2} \mathrm{~S} \mathrm{~cm}^{-1}$ respectively. The Nyquist plots of both liquid and gel electrolytes showed an inclined line response and the point of intersection of the $Z^{\prime \prime}$ versus $Z^{\prime}$ curve on the abscissa corresponds to the bulk resistance offered by the electrolyte to charge transport. The conductivities were also calculated from the resistance values 

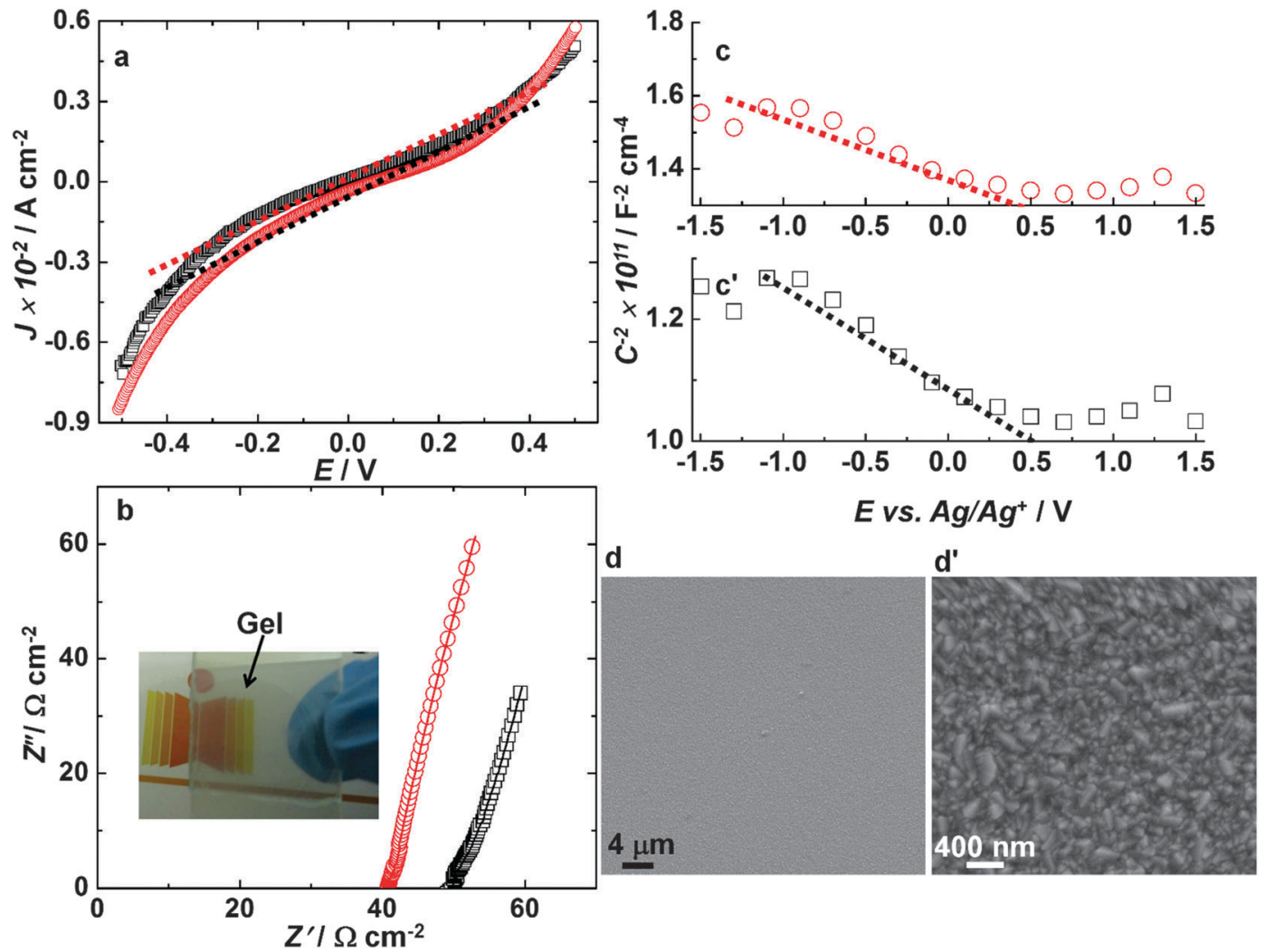

Fig. 6 (a) J-V characteristics, (b) Nyquist plots and (c, $\left.c^{\prime}\right)$ Mott-Schottky plots of a $0.1 \mathrm{M} \mathrm{Na}_{2} \mathrm{~S}$ solution in $3: 7(\mathrm{v} / \mathrm{v})$ water : $\mathrm{MeOH}(\square)$ and a $0.1 \mathrm{M} \mathrm{Na} 2 \mathrm{~S}$ gel with $4.1 \mathrm{wt} \%$ of $\mathrm{SiO}_{2}$ in $3: 7(\mathrm{v} / \mathrm{v})$ water : $\mathrm{MeOH}(\mathrm{O})$. The dotted lines in (a) are linear fits. Inset of $(\mathrm{b})$ is a digital photograph of the gel sandwiched between two glass substrates. The dotted lines in $(c)$ and $\left(c^{\prime}\right)$ represent $p$-type conduction and the intercepts correspond to their flat band potentials. (d) Low and $\left(d^{\prime}\right)$ high magnification images of the gel.

using: $\sigma\left(\mathrm{S} \mathrm{cm}^{-1}\right)=1 / R \times a\left(\Omega \mathrm{cm}^{-2}\right) \times d$ (thickness of the liquid/gel enclosed between the Pt electrodes in $\mathrm{cm})$. The conductivities were 0.01 and $0.012 \mathrm{~S} \mathrm{~cm}^{-1}$ for the liquid and gel electrolytes respectively. Since these values are close to the ones determined from $I-V$, they are reliable. It is imperative that the electrolyte should be transparent if it is to be used in a cell which will convert solar radiation into current, by front illumination, so as to enable the radiation to pass through the electrolyte and impinge on the photoanode. The photograph of the gel sandwiched between two glass plates is shown in the inset of Fig. 6b. It can be observed that the gel is highly transparent and is therefore apt for solar cell application. Furthermore, Scheme 1 also shows the photograph of the quasi solid state cell with the $\mathrm{Ag} / \mathrm{TiO}_{2} / \mathrm{CdS} / \mathrm{gel} / \mathrm{MWCNT}$ configuration and it is obvious that the gel is highly transmissive and can allow unhindered solar radiation permeation. To determine the effect of incorporating $\mathrm{SiO}_{2}$ in the liquid electrolyte on the hole transport capability of the liquid electrolyte, Mott-Schottky plots $\left(C^{-2}\right.$ versus $\left.E\right)$ were recorded for the liquid and gel electrolytes, in the solar cell configuration, under illumination $\left(100 \mathrm{~mW} \mathrm{~cm}{ }^{-2}\right)$ (Fig. $6 c$ and $c^{\prime}$ ). For both liquid and gel electrolytes, at negative potentials and above the flat band potential $\left(E_{\mathrm{fb}}\right.$ obtained by extrapolation to $C=0$ ), the $C^{-2}$ characteristic is linear with a negative slope, typical of p-type conductors, thus indicating that the gel is capable of conducting holes. The $E_{\mathrm{fb}}$ values were also almost similar ( $+0.5 \mathrm{~V}$ for liquid and +0.45 for the gel) for both the liquid and the gel, which endorses the similarity between them. The low and high magnification images of the gel are shown Fig. $6 \mathrm{~d}$ and $\mathrm{d}^{\prime}$. The gel has a nanoparticulate morphology, due to the presence of finely dispersed silica, and this morphology is uniform over multiple length scales, indicating that the components in the gel have been mixed uniformly, therefore, it is a homogeneous gel. The CV plots of the liquid and gel electrolytes are shown in Fig. S3 (ESI $\dagger$ ). From the plots, the reduction potential peaks (versus $\mathrm{Ag} / \mathrm{Ag}^{+}$) are observed at $-0.71 \mathrm{~V}$ for the liquid electrolyte and $-0.75 \mathrm{~V}$ for the gel electrolyte. These values versus vacuum are equal to $\sim-4.0 \mathrm{eV}$ for the liquid electrolyte and $\sim-3.95 \mathrm{eV}$ for the gel electrolyte and these have been used in the energy band diagram in Fig. 5. A detailed discussion is provided in the ESI. $\dagger$

\subsection{Solar cell characteristics}

Metal nanoparticles can also serve as recombination centers, and this parasitic effect is usually suppressed in plasmonic solar cells, with a thin coating of an insulating $\mathrm{SiO}_{2}$ or $\mathrm{TiO}_{2}$ layer. $^{28}$ In this study, $\mathrm{Ag}$ nanostructures were implanted in $\mathrm{TiO}_{2}$, so this snag was taken care of. The $J-V$ characteristics of solar cells with $\mathrm{TiO}_{2} / \mathrm{CdS}$ and $\mathrm{Ag} / \mathrm{TiO}_{2} / \mathrm{CdS}$ as photoanodes are shown in Fig. 7a and the solar cell parameters are summarized in Table 2 and Table S2 (ESI $\dagger$ ). A MWCNT/FTO electrode was 

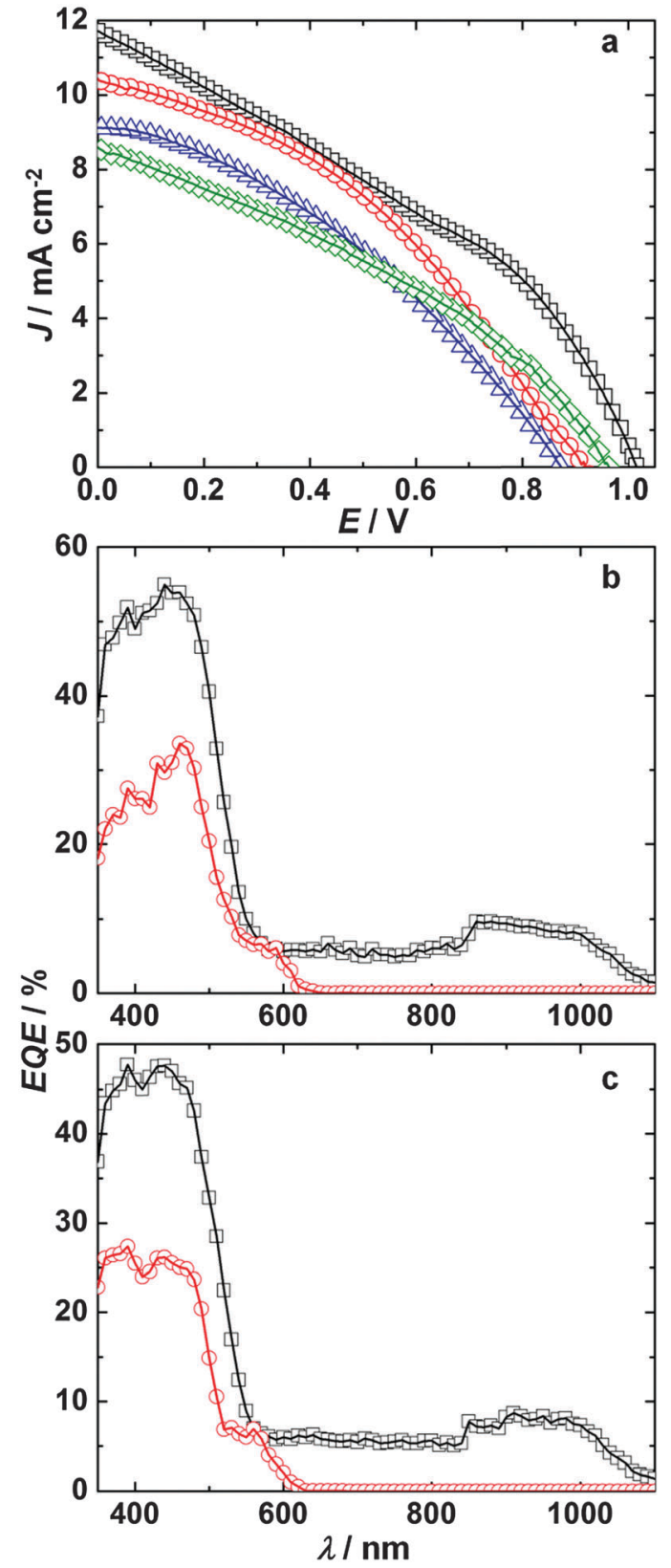

Fig. 7 (a) $J-V$ characteristics of photoelectrochemical solar cells with the following photoanodes: $\mathrm{TiO}_{2} / \mathrm{CdS}(\triangle)$ and $\mathrm{Ag} / \mathrm{TiO}_{2} / \mathrm{CdS}(\square)$ with a $0.1 \mathrm{M} \mathrm{Na}_{2} \mathrm{~S}$ solution in 3:7 (v/v) water: $\mathrm{MeOH}$ as the electrolyte and $\mathrm{TiO}_{2} / \mathrm{CdS}(\diamond)$ and $\mathrm{Ag} / \mathrm{TiO}_{2} / \mathrm{CdS}(\mathrm{O})$ in a $0.1 \mathrm{M} \mathrm{Na}_{2} \mathrm{~S}$ gel with $4.1 \mathrm{wt} \%$ of $\mathrm{SiO}_{2}$ in $3: 7(\mathrm{v} / \mathrm{v})$ water: $\mathrm{MeOH}$ as the electrolyte. All measurements in (a) were performed under 1 sun illumination (AM 1.5G). External quantum efficiency spectra of cells with the following photoanodes: $\mathrm{TiO}_{2} / \mathrm{CdS}(\mathrm{O})$ and $\mathrm{Ag} / \mathrm{TiO}_{2} / \mathrm{CdS}(\square)$ with (b) a $0.1 \mathrm{M} \mathrm{Na}_{2} \mathrm{~S}$ solution in $3: 7(\mathrm{v} / \mathrm{v})$ water: $\mathrm{MeOH}$ and (c) a $0.1 \mathrm{M} \mathrm{Na}_{2} \mathrm{~S}$ gel with $4.1 \mathrm{wt} \%$ of $\mathrm{SiO}_{2}$ in $3: 7(\mathrm{v} / \mathrm{v})$ water $\mathrm{MeOH}$, as electrolytes. In (a-c), a MWCNT/FTO assembly was used as the counter electrode.

employed as the counter electrode and a gel or liquid containing $\mathrm{S}^{2-}$ ions was used the electrolyte. The morphology and the corresponding lattice scale image of the MWCNT electrode are shown in Fig. S5 (ESI $\dagger$ ). The $J-V$ curves were obtained under one sun illumination $\left(100 \mathrm{~mW} \mathrm{~cm}^{-2}\right)$ of AM $1.5 \mathrm{G}$ light. The best
Table 2 Solar cell parameters of cells with $0.1 \mathrm{M} \mathrm{Na}_{2} \mathrm{~S}$ electrolyte, exposed cell area: 0.10 to $0.15 \mathrm{~cm}^{2}$, under 1 sun illumination $\left(100 \mathrm{~mW} \mathrm{~cm} \mathrm{~cm}^{-2}\right.$ ) with the listed photoanodes; all cells with MWCNT/FTO as the counter electrode

\begin{tabular}{lclllc}
\hline $\begin{array}{l}\text { Photoanode } \\
\text { configuration }\end{array}$ & $\begin{array}{l}V_{\mathrm{OC}} \\
(\mathrm{mV})\end{array}$ & $\begin{array}{l}J_{\mathrm{SC}} \\
\left(\mathrm{mA} \mathrm{cm}{ }^{-2}\right)\end{array}$ & $\mathrm{FF}$ & $\begin{array}{l}\eta_{\text {best }} \\
(\%)\end{array}$ & $\eta_{\mathrm{avg}}(\%)$ \\
\hline $\mathrm{TiO}_{2} / \mathrm{CdS}-$ liquid & 872.5 & 9.08 & 36.71 & 2.90 & $2.87 \pm 0.03$ \\
$\mathrm{TiO}_{2} / \mathrm{CdS}-$ gel & 958.8 & 8.59 & 35.037 & 2.88 & $2.8525 \pm 0.0275$ \\
$\mathrm{Ag}_{\mathrm{TiO}} / \mathrm{CdS}-l i q u i d$ & 1021 & 11.67 & 35.84 & 4.27 & $4.21 \pm 0.06$ \\
$\mathrm{Ag} / \mathrm{TiO}_{2} / \mathrm{CdS}$-gel & 920.9 & 10.43 & 38.0 & 3.65 & $3.47 \pm 0.18$
\end{tabular}

PCE or $\eta$ of the $\mathrm{TiO}_{2} / \mathrm{CdS}$ and $\mathrm{Ag} / \mathrm{TiO}_{2} / \mathrm{CdS}$-liquid based cells were 2.9 and $4.27 \%$, respectively, and the corresponding PCE values for the gel based cells were 2.88 and $3.65 \%$ respectively. While there was no significant difference in the performance of the cell with $\mathrm{TiO}_{2} / \mathrm{CdS}$, be it a liquid or gel electrolyte, but the difference was slightly pronounced when the liquid was replaced by a gel in the $\mathrm{Ag} / \mathrm{TiO}_{2} / \mathrm{CdS}$ cell, the PCE decreased by $14.5 \%$ for the gel cell. However, considering that the gel electrolyte is capable of working in a manner akin to the liquid electrolyte, albeit the slight performance difference in the metal nanostructure based gel cell, it shows promise for solar cell applications and further optimization can be done in the future to improve it still further. The cell parameters for the best performing $\mathrm{Ag} / \mathrm{TiO}_{2} / \mathrm{CdS}$ based liquid cell were: $V_{\mathrm{OC}}$ (open circuit voltage) $=1021 \mathrm{mV}, J_{\mathrm{SC}}$ (short circuit current density) $=$ $11.67 \mathrm{~mA} \mathrm{~cm}^{-2}, \mathrm{FF}=35.98$ and $\eta=4.27 \%$. $V_{\mathrm{OC}}$ is defined as the potential difference between the redox potential of the electrolyte and the Fermi level of the semiconductor. The unusually high $V_{\mathrm{OC}}$ for this cell is attributed to the shift in the Fermi level of $\mathrm{TiO}_{2}$ to more negative potentials versus NHE, when it is brought in contact with a metal, i.e., the $\mathrm{Ag}$ nanostructure layer in the $\mathrm{Ag} / \mathrm{TiO}_{2} / \mathrm{CdS}$ cell. The increase in $J_{\mathrm{SC}}$ for the $\mathrm{Ag} / \mathrm{TiO}_{2} / \mathrm{CdS}$ based liquid cell compared to the $\mathrm{TiO}_{2} / \mathrm{CdS}$ based liquid cell is due to the ability of $\mathrm{Ag}$ nanostructures to serve as efficient electron acceptors. The photoexcited electrons in the $\mathrm{Ag} / \mathrm{TiO}_{2} /$ CdS based cell (be it liquid or gel based) are rapidly captured by $\mathrm{Ag}$ nanostructures and delivered to FTO. Furthermore, the ability of $\mathrm{Ag}$ nanostructures to increase the absorption of $\mathrm{TiO}_{2} / \mathrm{CdS}$ by (i) near-field plasmonic coupling effects and (ii) optical path length increase induced by far-field light scattering effects also contribute to increased photocurrents in the $\mathrm{Ag} /$ $\mathrm{TiO}_{2} / \mathrm{CdS}$ assembly. These advantageous characteristics are not available to the $\mathrm{TiO}_{2} / \mathrm{CdS}$ assembly and hence the performance of the $\mathrm{TiO}_{2} / \mathrm{CdS}$ based cells is inferior to that of the $\mathrm{Ag} / \mathrm{TiO}_{2} / \mathrm{CdS}$ based cells. For the latter electrode when used with the gel electrolyte, $V_{\mathrm{OC}}$ and $J_{\mathrm{SC}}$ were $\sim 921 \mathrm{mV}$ and $10.43 \mathrm{~mA} \mathrm{~cm}^{-2}$. The quality of the contact between this particular electrode and the gel may be the reason for the slightly lowered performance. But this gel/photoanode interface is as good as the liquid/photoanode interface when the photoanode is $\mathrm{TiO}_{2} / \mathrm{CdS}$. The PCE for the liquid cell showed a $47.24 \%$ improvement and that for the gel cell exhibited a $26.74 \%$ rise, when $\mathrm{TiO}_{2} / \mathrm{CdS}$ was replaced by the $\mathrm{Ag} / \mathrm{TiO}_{2} / \mathrm{CdS}$ photoanode. It is obvious that $\mathrm{Ag}$ nanostructures favorably impact the solar cell performance. In a previous report, loading of plasmonic silica-capped nanoprisms of $\mathrm{Ag@SiO}_{2}$ 
in the titania photoanode resulted in a $32 \pm 17 \%$ increase in the overall PCE of the DSSC, driven primarily by an increase in the short circuit current density. This plasmonic efficiency enhancement resulted in an 8.4\% PCE for their highest performing device. ${ }^{39}$ In another report, asymmetric $\mathrm{Au}-\mathrm{SiO}_{2}$ clusters were integrated with the dye sensitized $\mathrm{ZnO}$ nanosheets, and an efficiency of $2.24 \%$ was achieved compared to an efficiency of $1.79 \%$ for the control cell without the plasmonic clusters. ${ }^{40}$ In another study, silica-coated nanocubes ( $\left.\mathrm{Au} @ \mathrm{SiO}_{2}\right)$ embedded in the photoanodes of DSSCs showed a PCE of 7.8\% relative to $5.8 \%$ of reference $\left(\mathrm{TiO}_{2}\right.$ only) devices, resulting in a $34 \%$ improvement in DSSC performance. ${ }^{41}$ It is obvious that metal plasmons can improve PCE values of QDSCs, just like they do in DSSCs.

The $J-V$ characteristics of the cells based on $\mathrm{Ag} / \mathrm{TiO}_{2} / \mathrm{CdS}$ and $\mathrm{TiO}_{2} / \mathrm{CdS}$ were also measured after subjecting them to discontinuous 1 sun illumination for $3 \mathrm{~h}$. The plots and solar cell parameters are provided in the ESI $\dagger$ (Fig. S4 and Table S3). The PCE of the $\mathrm{TiO}_{2} / \mathrm{CdS}$ based cell dropped from 2.9 to $2.83 \%$ and that of the $\mathrm{Ag} / \mathrm{TiO}_{2} / \mathrm{CdS}$ based cell decreased from 4.27 to $3.81 \%$. The $\mathrm{TiO}_{2} / \mathrm{CdS}$ based cell showed an efficiency drop by 9.5\% and the $\mathrm{Ag} / \mathrm{TiO}_{2} / \mathrm{CdS}$ based cell's efficiency dropped by $6.1 \%$. The $J-V$ plots and the solar cell parameters are provided below for ready reference and also in the ESI. $\dagger$ The quantum dots tend to undergo photodecomposition and separate from the electrode, which is the most probable reason for the efficiency drop. In the presence of Ag nanostructures, the CdS QDs are less susceptible to dissolution in the sulfide electrolyte, as can be judged from the relative percentage drops. The crystallinity of the $\mathrm{Ag}$ nanostructures render them stable to the electrolyte. In the past, for a cell based on a $\mathrm{CdSe} / \mathrm{CdS} / \mathrm{ZnO}$ photoanode, the $J_{\mathrm{SC}}$ decreased upon illumination for $\sim 1.4 \mathrm{~h}$; the QDs peel off, which causes the photocurrent decline. ${ }^{42}$

The benefit of incorporating $\mathrm{Ag}$ nanostructures in the $\mathrm{TiO}_{2} /$ CdS photoanode was further reflected in the variation in external quantum efficiencies (EQEs) of solar cells based on electrodes with and without Ag nanostructures. The EQE versus wavelength for cells with $\mathrm{TiO}_{2} / \mathrm{CdS}$ and $\mathrm{Ag} / \mathrm{TiO}_{2} / \mathrm{CdS}$ electrodes and with liquid and gel electrolytes are shown in Fig. $7 \mathrm{~b}$ and $\mathrm{c}$ and the EQE response of pristine $\mathrm{TiO}_{2}$ is shown in Fig. S6 (ESI $\dagger)$. The maximum EQE is $\sim 55 \%(\lambda=440 \mathrm{~nm})$, attained by the $\mathrm{Ag} / \mathrm{TiO}_{2} / \mathrm{CdS}$ cell, with the liquid electrolyte. For the same electrode with the gel electrolyte, the maximum EQE was $\sim 48 \%$. In contrast, for the $\mathrm{TiO}_{2} / \mathrm{CdS}$ based, liquid electrolyte containing cell, the highest EQE was $\sim 33 \%$, and it was $27 \%$, when the gel electrolyte was used instead. The ability of $\mathrm{Ag}$ nanostructures to improve the light harvesting capability of the $\mathrm{TiO}_{2} / \mathrm{CdS}$ photoanode was clearly observed in the slight increase in the EQE in the 900 to $1000 \mathrm{~nm}$ wavelength region observed for the $\mathrm{Ag} / \mathrm{TiO}_{2} /$ CdS photoanode, which coincides with the longitudinal plasmonic mode of Ag nanostructures. Ag nanorods also scatter light, which increases the path length of light within the photoanode, thus improving the photocurrents. This increase was observed in both liquid and gel electrolyte based cells. The increase is caused by the plasmonic coupling of $\mathrm{Ag}$ nanostructures with the CdS QDs and light scattering effects.

\section{Conclusions}

Inclusion of $\mathrm{Ag}$ nanostructures in $\mathrm{TiO}_{2}$ yielded an $\mathrm{Ag} / \mathrm{TiO}_{2}$ assembly, onto which CdS QDs were tethered by a SILAR process. Optimization of the morphology of Ag nanostructures was accomplished by the evaluation of PCEs of cells based on $\mathrm{Ag} / \mathrm{TiO}_{2} / \mathrm{CdS}$ encompassing either a mixed morphology of Ag nanorods juxtaposed with nanoparticles or $\mathrm{Ag}$ nanorods or $\mathrm{Ag}$ nanoparticles. Illumination driven rapid electron relay from CdS to $\mathrm{TiO}_{2}$ to $\mathrm{Ag}$ was followed by absorption and emission quenching and decay analysis. Ag nanostructures (a) absorb both visible and NIR portions of the solar spectrum due to transverse and longitudinal surface plasmon resonance modes, and thus afford near field enhancement, (b) impart far-field increment by light scattering, and (c) work as efficient electron acceptors as they readily accept photogenerated electrons from CdS via $\mathrm{TiO}_{2}$ and deliver them to the current collector to which they are linked, in the $\mathrm{Ag} / \mathrm{TiO}_{2} / \mathrm{CdS}$ photoanode. These complementary factors are responsible for a considerably increased PCE of $4.27 \%$ and a maximum $\mathrm{EQE}$ of $55 \%(\lambda=440 \mathrm{~nm})$, achieved for the $\mathrm{Ag} / \mathrm{TiO}_{2} / \mathrm{CdS}$ based cell, compared to the $\mathrm{TiO}_{2} / \mathrm{CdS}$ based cells. Furthermore, an alternate to the liquid $\mathrm{S}^{2-}$ electrolyte was prepared by converting it into a gel using fumed silica. The solar cell parameters declined slightly for the gel based cells as opposed to the liquid based cells, despite the gel having comparable redox potentials, p-type conduction behavior, transparency and conductivity. The $\mathrm{Ag} / \mathrm{TiO}_{2} / \mathrm{CdS}$ based gel cell still delivered a PCE greater by $32 \%$ compared to the $\mathrm{TiO}_{2} / \mathrm{CdS}$ based gel cell. The stellar performance of the $\mathrm{Ag} / \mathrm{TiO}_{2} /$ CdS photoanode opens up opportunities to design new photoanode architectures by use of plasmonic and highly conductive mixed morphology metal nanostructures, so that remarkably high efficiencies for QDSCs, maybe even comparable to their dye-sensitized counterparts, can be realized.

\section{Acknowledgements}

Financial support from Department of Science \& Technology (DST/TM/SERI/2K12/11(G)) is gratefully acknowledged. One of the authors (PNK) thanks UGC for the grant of junior research fellowship.

\section{References}

1 I. K. Ding, J. Zhu, W. Cai, S. J. Moon, N. Cai, P. Wang, S. M. Zakeeruddin, M. Grätzel, M. L. Brongersma, Y. Cui and M. D. McGehee, Adv. Energy Mater., 2011, 1, 52-57.

2 R. Zhou, Q. Zhang, J. Tian, D. Myers, M. Yin and G. Cao, J. Phys. Chem. C, 2013, 117, 26948-26956.

3 H. Choi, J. G. Radich and P. V. Kamat, J. Phys. Chem. C, 2014, 118, 206-213.

4 P. N. Kumar, S. Mandal, M. Deepa, A. K. Srivastava and A. G. Joshi, J. Phys. Chem. C, 2014, 118, 18924-18937.

5 C. H. Lai and P.-T. Chou, Chem. Commun., 2011, 47, 3448-3450.

6 M. H. Jung and M. G. Kang, J. Mater. Chem., 2011, 21, 2694-2700. 
7 R. Narayanan, M. Deepa and A. K. Srivastava, Phys. Chem. Chem. Phys., 2012, 14, 767-778.

8 P. Sheng, W. Li, J. Cai, X. Wang, X. Tong, Q. Cai and C. a. Grimes, J. Mater. Chem. A, 2013, 1, 7806-7815.

9 C. Y. Kuo, M. S. Su, C. S. Ku, S. M. Wang, H. Y. Lee and K.-H. Wei, J. Mater. Chem., 2011, 21, 11605-11612.

10 L. H. Lai, L. Protesescu, M. V Kovalenko and M. a. Loi, Phys. Chem. Chem. Phys., 2014, 16, 736-742.

11 V. González-Pedro, C. Sima, G. Marzari, P. P. Boix, S. Giménez, Q. Shen, T. Dittrich and I. Mora-Seró, Phys. Chem. Chem. Phys., 2013, 15, 13835-13843.

12 A. Zaban, O. I. Mic, B. A. Gregg and A. J. Nozik, Langmuir, 1998, 14, 3153-3156.

13 R. S. Dibbell and D. F. Watson, J. Phys. Chem. C, 2009, 113, 3139-3149.

14 V. Gonzales-Pedro, X. Xu, I. Mora-Seró and J. Bisquert, ACS Nano, 2010, 4, 5783-5790.

15 J. G. Radich, R. Dwyer and P. V Kamat, J. Phys. Chem. Lett., 2011, 2, 2453-2460.

16 P. K. Santra and P. V. Kamat, J. Am. Chem. Soc., 2012, 134, 2508-2511.

17 Z. Pan, I. Mora-Seró, Q. Shen, H. Zhang, Y. Li, K. Zhao, J. Wang, X. Zhong and J. Bisquert, J. Am. Chem. Soc., 2014, 136, 9203-9210.

18 H. Imahori, T. Umeyama and S. Ito, Acc. Chem. Res., 2009, 42, 1809-1818.

19 L. Wang, H. Zhang, C. Wang and T. Ma, ACS Sustainable Chem. Eng., 2013, 1, 205-208.

20 G. J. Meyer, ACS Nano, 2010, 4, 4337-4343.

21 T. Hirakawa and P. V. Kamat, Langmuir, 2004, 20, 15645-15647.

22 M. D. Brown, T. Suteewong, R. S. S. Kumar, V. D'Innocenzo, A. Petrozza, M. M. Lee, U. Wiesner and H. J. Snaith, Nano Lett., 2011, 11, 438-445.

23 M. Li, S. K. Cushing, Q. Wang, X. Shi, L. A. Hornak, Z. Hong and N. Wu, J. Phys. Chem. Lett., 2011, 2, 2125-2129.

24 J. Qi, X. Dang, P. T. Hammond and A. M. Belcher, ACS Nano, 2011, 5, 7108-7116.
25 Y. H. Jang, Y. J. Jang, S. T. Kochuveedu, M. Byun, Z. Lin and D. H. Kim, Nanoscale, 2014, 6, 1823-1832.

26 S. W. Sheehan, H. Noh, G. W. Brudvig, H. Cao and C. a. Schmuttenmaer, J. Phys. Chem. C, 2013, 117, 927-934.

27 Q. Xu, F. Liu, Y. Liu, K. Cui, X. Feng, W. Zhang and Y. Huang, Sci. Rep., 2013, 3, 2112.

28 P. V. Kamat, H. Choi and W. T. Chen, ACS Nano, 2012, 6, 4418-4427.

29 X. Dang, J. Qi, M. T. Klug, P. Y. Chen, D. S. Yun, N. X. Fang, P. T. Hammond and A. M. Belcher, Nano Lett., 2013, 13, 637-642.

30 W. L. Liu, F. C. Lin, Y. C. Yang, C. H. Huang, S. Gwo, M. H. Huang and J. S. Huang, Nanoscale, 2013, 5, 7953-7962.

31 Y. Sun and Y. Xia, Adv. Mater., 2002, 14, 833-837.

32 Y. Sun, B. Gates, B. Mayers and Y. Xia, Nano Lett., 2002, 2, 165-168.

33 S. S. Kim, S. I. Na, J. Jo, D. Y. Kim and Y. C. Nah, Appl. Phys. Lett., 2008, 93, 073307.

34 S. Woo Jung, J. H. Kim, H. Kim, C. J. Choi and K. S. Ahn, J. Appl. Phys., 2011, 110, 044313.

35 M. Jakob, H. Levanon and P. V. Kamat, Nano Lett., 2003, 3, 353-358.

36 P. N. Kumar, R. Narayanan, M. Deepa and A. K. Srivastava, J. Mater. Chem. A, 2014, 2, 9771-9783.

37 N. Guijarro, Q. Shen, S. Gimenez, I. Mora-Sero, J. Bisuert, T. Lana-villarreal, T. Toyoda and R. Gomez, J. Phys. Chem. C, 2010, 114, 22352-22360.

38 L. E. I. Liu, K. Song, X. Li and Q. Guo, J. Inclusion Phenom. Macrocyclic Chem., 2001, 35-39.

39 M. K. Gangishetty, K. E. Lee, R. W. J. Scott and T. L. Kelly, ACS Appl. Mater. Interfaces, 2013, 5, 11044-11051.

$40 \mathrm{H}$. Li, K. Yuan, Y. Zhang and J. Wang, ACS Appl. Mater. Interfaces, 2013, 5, 5601-5608.

41 H. F. Zarick, O. Hurd, J. A. Webb, C. Hungerford, W. R. Erwin and R. Bardhan, ACS Photonics, 2014, 1, 806-811.

42 H. Kim, I. Hwang and K. Yong, ACS Appl. Mater. Interfaces, 2014, 6, 11245. 